\title{
Parental choice, neighbourhood segregation or cream skimming? An analysis of school segregation after a generalized choice reform
}

\author{
Anders Böhlmark ${ }^{1}$ • Helena Holmlund ${ }^{2}$. \\ Mikael Lindahl ${ }^{3}$
}

Received: 2 December 2015 / Accepted: 4 April 2016/Published online: 20 April 2016

(C) The Author(s) 2016. This article is published with open access at Springerlink.com

\begin{abstract}
This paper studies the evolution of school segregation in Sweden in the aftermath of the 1992 universal voucher reform, which spurred the establishment of new independent schools and introduced parental choice. We assess the relative importance of neighbourhood segregation, parental choice and the location of independent schools for school segregation. In particular, we exploit variation in school choice opportunities across municipalities and provide descriptive evidence that in regions where
\end{abstract}

\section{Responsible editor: Erdal Tekin}

We are grateful to Magnus Bygren, Marcus Eliason, Oskar Nordström Skans and an anonymous referee for valuable comments and suggestions. We would also like to thank the seminar and conference participants at Uppsala (IFAU), VATT Helsinki, SUDA Stockholm University, ESPE 2013 in Aarhus and EALE 2014 in Ljubliana. Financial support from the Swedish Research Council for Health, Working Life and Welfare (FORTE) [grant no: 2013-0645] and the Swedish Research Council (Vetenskapsrådet) [grant number D0199201; 2007-2283] is gratefully acknowledged. Mikael Lindahl is a Royal Swedish Academy of Sciences Research Fellow supported by a grant from the Torsten and Ragnar Söderberg Foundation and also acknowledges financial support from the Scientific Council of Sweden and the European Research Council [ERC starting grant 241161].

Helena Holmlund

helena.holmlund@ifau.uu.se

Anders Böhlmark

anders.bohlmark@sofi.su.se

Mikael Lindahl

Mikael.Lindahl@economics.gu.se

1 Swedish Institute for Social Research, IFAU and CREAM, Stockholm University, 106 91 Stockholm, Sweden

2 Institute for Evaluation of Labour Market and Education Policy (IFAU), Box 513, 75120 Uppsala, Sweden

3 Department of Economics, CESifo, IFAU, IZA and UCLS, University of Gothenburg, P.O. Box 640, 40530 Göteborg, Sweden 
school choice has become more prevalent, school segregation between immigrants and natives, and between children of high/low educated parents, has increased more than in regions where choice is limited. This result also holds when we account for residential segregation and focus on excess segregation over and above the segregation that would occur if all pupils attended their assigned schools. We find that the increase in school segregation 15 years after the reform that can be attributed to choice is relatively small.

Keywords School segregation $\cdot$ School choice

JEL classification $\mathrm{I} 20 \cdot \mathrm{J} 10 \cdot \mathrm{H} 44$

\section{Introduction}

School segregation has received a lot of attention in the education debate because of a perception that segregation is accompanied by unequal resources, and because publicly funded education is one of few policy areas where society can act to level the playing field and create equal opportunities for children with different family backgrounds. There is also a general concern that social cohesion in society is adversely affected if interactions between children from different backgrounds are limited (Levin 1998). In the academic context, education research takes a specific interest in the grouping of students by ability and background, because of its potential consequences for the education production function. Segregation might imply negative effects on achievement for low-ability pupils through peer effects, but these may be offset by positive 'tracking' effects if it is more efficient to teach a homogenous group rather than a mixed group (Duflo et al. 2011). That said, segregation might still have consequences for other outcomes: Billings et al. (2014) show that re-segregation policies in the USA have increased youth crime, but that the negative effects on test scores were dampened by compensatory resource allocation.

Despite the vast literature on segregation up to date, there is a limited understanding of the mechanisms that give rise to school segregation. Generally, school segregation can be driven either by residential segregation across neighbourhoods or by factors related to mechanisms for assigning pupils to schools. Residential segregation may be a result of residential sorting (including Tiebout choice) but can also stem from historical and institutional factors (such as housing policies or neighbourhood ethnic enclaves, etc). Mechanisms and rules for assigning pupils to schools include catchment area boundaries and school choice. Through school choice, families get the opportunity to opt out of the assigned school, and this opportunity may have different consequences for segregation depending on the school choice policy regulation (e.g. through schools' possibilities to cream-skim the best students through selective admissions criteria or through strategic school locations).

To address the question of which are the most important mechanisms behind school segregation, this paper is the first to simultaneously analyze the key determinants of school segregation: residential segregation and school choice. We try to separate school choice into pupils' choice of opting out of the assigned school and schools' efforts to cream-skim the best pupils. We are able to assess these three components, exploiting a policy change that introduced generalized school choice in Sweden, using excellent data on the full population of 16-year-old students, including information on their 
socioeconomic background, migration histories and the schools they attend, over a time period of more than 20 years.

Our focus is on segregation with respect to pupils' migration history and socioeconomic background. The former dimension is particularly important in light of the current EU migrant crisis and highly relevant for Sweden which has experienced a refugee-immigration per capita eight times the EU15 (i.e. the pre-2004 EU members) average in 2005-2014 (Ruist 2015). The recent development was preceded by a considerable growth of the refugee immigrant population since the 1980s. For the age-group that we study, the fraction of foreign-born 16-year olds increased from 5 to $10 \%$ between the late 1980 s and 2000 , and an increasing share of foreign-born students arrived after school-starting age. The fraction of students who are either foreign-born or born in Sweden to two foreign-born parents has also increased and reached $17 \%$ in 2000 (Holmlund et al. 2014). This development has raised concerns that schools with a high concentration of immigrant students will fail to keep up with educational standards (see e.g. Ministry of Education 2011).

In the empirical analysis, we exploit variation in the growth of school choice opportunities across regions in the aftermath of the 1992 choice reform: publicly funded voucher schools have opened up in some regions, but in others the choice opportunities are limited. We thus relate the change in school segregation over time at the regional level to corresponding changes in the degree of neighbourhood segregation, cream skimming and parental choice (i.e. opting out of the assigned school). We adopt a segregation index measuring peer exposure, which intuitively solves the 'small unit bias' problem of any segregation index (Carrington and Troske 1997; Åslund and Nordström Skans, 2010). While our purpose is not to establish causal effects, this approach makes it possible to assess the relative importance of the components of school segregation, and to empirically rule out components that contribute very little. We further discuss whether the results can be generalized to other settings of universal school choice.

Elements of choice have become prevalent in many education systems, motivated by the idea that choice and competition should increase efficiency and boost educational outcomes, while public funding should still guarantee equal access and quality for students of different backgrounds. In the USA, alternatives to traditional public schools (e.g. charter schools) are on the rising (NAPCS 2014). The UK has a tradition of a variety of school types, including 'faith schools', that are publicly funded, and parental choice has been increasingly advocated (Gibbons et al. 2008). Chile introduced a universal school voucher scheme in 1981 which has led to growing private enrolment (MacLeod and Urquiola 2012). Similarly, one of the most dramatic choice reforms took place in the early 1990s in Sweden, which moved from a system with virtually no choice and no private alternatives, to a voucher-based system with choice between public and so-called independent, publicly funded, schools. As a consequence, a sector of independent schools has emerged, and as of today about $12 \%$ of 16 -year-old pupils attend an independent school. This school choice reform was very radical, also in an international perspective, and many regarded it as being at odds with the traditional role for education in Sweden.

The Swedish voucher system is based upon the idea to give equal opportunities to all pupils: the voucher follows the pupil to his/her school of choice. Schools are not allowed to select pupils by ability nor are they allowed to charge tuition fees on top of 
the voucher. Despite the design of the voucher system, children with advantaged backgrounds are more likely to attend independent schools. In Table 7 in Appendix 1 we show that in 2009, pupils with highly educated parents were almost twice as likely to attend an independent school compared to pupils whose parents had lower education. On the contrary, immigrants and natives have similar probabilities of opting out to an independent school, but the probability to attend independent schools appears to be particularly large for children with Swedish origin who live in areas with a large immigrant population (Andersson et al. 2012; Holmlund et al. 2014). These empirical patterns correspond to the so-called white flight in the USA, and have raised concerns that school segregation is on the rising, and that schools in disadvantaged areas will be drained of their best students.

Recent studies confirm that school segregation in Sweden has increased in some dimensions (Fredriksson and Vlachos 2011; National Agency for Education 2012), and the timing of this increase corresponds to an increased prevalence of school choice. While recent research on the choice reform finds that choice and competition has had small positive effects on test scores on average (Böhlmark and Lindahl 2015; Wondratschek et al. 2013), there is a perception that choice can explain rising school segregation. ${ }^{1}$ Prominent education academics have argued that the main societal cost of school choice is the adverse impact on school segregation which might lead to a balkanization of the Swedish society. ${ }^{2}$ There is, however, very limited evidence on the actual mechanisms behind the increase in school segregation in Sweden. Although school choice is one possible determinant, the evolution of school segregation may also be explained by residential segregation. Furthermore, if school choice has contributed to increased school segregation, it is central for policy purposes to understand whether it is choice between public schools or the location and choice of independent schools that give rise to segregation.

We are able to reveal a number of interesting findings. First, we find that overall, school segregation has increased between pupils characterized by native/immigrant background and by high/low education background. Neighbourhood segregation has also increased in these dimensions and is the most important factor in explaining school segregation. Second, in regions where school choice has become more prevalent, school segregation between immigrants and natives, and between pupils with high/low parental education, has increased over and above what we should expect given neighbourhood segregation. The estimates indicating a positive association between school choice and school segregation between immigrants and natives are robust throughout a number of empirical specifications. However, comparing the levels of school segregation in Sweden to other countries, we conclude that the growth over time

\footnotetext{
${ }^{1}$ There are several other recent studies of school choice in Sweden. Hensvik (2012) finds that the establishment of independent schools is associated with higher teacher salaries and higher wage dispersion among teachers. Edmark et al. (2014) find no evidence on heterogeneous impacts of school choice among students with varying demographics and socioeconomic characteristics. Shafiq and Myers (2014) find no evidence of a decline in civic attitudes (towards the rights of ethnic minorities and immigrants) between 1999 and 2009 among 14-year-old students, and that independent schools have a small advantage in civic attitudes (controlling for student characteristics).

${ }^{2}$ Henry Levin, William H. Kilpatrick Professor of Economics and Education at Columbia University, in an interview on the Swedish radio programme Vetandets värld, March 19th, 2013.
} 
has not been sufficiently large to significantly alter Sweden's position as a low-tomedium segregated country.

The remainder of the paper is organized as follows: Section 2 gives some background to the analysis in this paper. We provide a short literature review, discuss the school reforms that took place in Sweden in the early 1990s and provide a theoretical discussion of how school segregation interrelates with the choice of school, pupils' residential neighbourhoods and schools' locations. Section 3 describes the data and presents the segregation measures that we adopt. Section 4 analyzes school segregation over time in Sweden. We show national trends as well as trends across regions with different degrees of parental choice. In Section 5, we take the analysis one step further and estimate the association between school segregation and school choice by using variation in the growth of choice between municipalities, controlling for the degree of residential segregation and the location of independent schools (a form of cream skimming). Section 6 interprets our findings and concludes.

\section{Background}

\subsection{A short review of previous research on school choice and segregation}

Several research topics related to school choice and student segregation are relevant for this study and have been explored in the previous literature. One strand of the literature studies the decision to opt out from assigned schools. The focus is on describing the characteristics of those who leave, and on how the composition of pupils in the old and the new schools impacts the decision to leave or remain in the assigned school. There is some evidence that those families who make the choice to opt out of the assigned school, either to non-public schools or, when possible, to alternative public schools, are more advantaged (see Levin 1998, for a review), and that these families put higher value on the academic achievement of schools (Hastings et al. 2005). There is also evidence of 'white flight' and of so-called tipping points for schools, meaning that white students opt out if the minority share increases above a certain threshold (Card et al. 2008). ${ }^{3}$ Other studies specifically focus on how choice to private schools impacts the composition between private and public schools, in environments where private schools can select their students. Hsieh and Urquiola (2006) find that more private school choice in Chile lead to a higher fraction of high SES students in the private school sector. Ladd and Fiske (2001) compare segregation in three urban areas in New Zealand over a period where a radical national school choice reform was enacted. They find evidence of European families moving their children to higher performing schools and to schools with less minority students. However, Figlio and Stone (2001) find that fewer public school choice opportunities especially induce students from high SES backgrounds to opt out to the private school sector.

Another strand of the literature studies the impact of choice on school segregation directly, while controlling for residential segregation. Burgess et al. (2007) use data from three cities in the UK and analyze school segregation at the secondary school level. They measure segregation with the dissimilarity index and regress school segregation on the

\footnotetext{
$\overline{{ }^{3} \text { For a recent study using Swedish }}$ data, see Spaiser et al. (2016).
} 
number of schools available within commuting distance. The evidence points to increased school segregation by immigrant background and parental income, as well as by ability. Söderström and Uusitalo (2010) study an admission selection reform that increased school choice opportunities for students applying to Stockholm high schools in 2000. They compare changes before and after the reform using neighbouring municipalities as controls and find that the reform implied increased segregation by ability, family background and between natives and immigrants. ${ }^{4}$

This is not a comprehensive review of the literature, but almost all of these studies indicate that choice tends to increase segregation. The aim of this study is therefore to understand whether a generalized school choice system with vouchers, designed to give equal access to all children regardless of their family background, is associated with increased school segregation, and if so, how large this association is and what are the underlying mechanisms. We believe that there are some general insights to be learned about school choice and the mechanisms that give rise to segregation, which can be generalized to other settings where universal school vouchers are introduced.

\subsection{Institutional background: Sweden's compulsory school and the 1992 school choice reform}

Before 1992, pupils were assigned to, and required to attend, the public school in their local catchment area. Only under special circumstances, could a student attend another public school. An alternative was to opt for one of the few private schools that existed. However, these accounted for less than $1 \%$ of total enrolment, and these schools attracted a rather special selection of pupils. ${ }^{5}$ Therefore, under the pre-reform setting, the only way parents could influence which school their children attended was through their residential choice.

In 1992, Sweden introduced a nation-wide voucher system. Non-public schools could receive approval (by the Swedish National Agency of Education, NAE) to become voucher schools. Students' home municipalities had to provide voucher schools with a grant, based on the average per-pupil expenditure in the public school system, for each pupil who chose to enrol in a voucher school. This new law gave rise to a new type of non-public schools, 'independent schools', whose existence depended on funding through vouchers. ${ }^{6}$ Even though new independent schools need approval by the NAE, this does not seem to have been a great obstacle for market entry since the number of rejected applications was small up to the year $2009 .^{7}$

\footnotetext{
${ }^{4}$ Östh et al. (2013) study school choice in Sweden indirectly by a "counterfactual approach," where students in the post-reform period are assigned to the expected school in the pre-reform period. They find that ability segregation has increased as a consequence of choice.

5 The non-public schools existing prior to 1992 were boarding schools (attracting a small selection of upperclass children); schools for pupils with special needs; international schools (mainly for foreign pupils); Christian-community schools; and special pedagogy schools (e.g. Waldorf and Montessori).

${ }^{6}$ Independent schools were initially allowed to charge moderate tuition fees, but the right to charge fees was abolished in 1997. At the same time, the funding rule was changed so that the grant to independent schools was determined on the same grounds as grants to public schools, i.e., $100 \%$ of the average per-pupil expenditure in the municipality. In the early reform years, the required voucher was $85 \%$ of the average per-pupil expenditure.

${ }^{7}$ Since 1997, the NAE has to consider potential negative consequences for the public schools in the local authority when deciding upon an application.
} 
The independent schools are allowed to deviate from the national curriculum. In addition, there are no restrictions on the ownership structure of independent schools eligible for public funding - whether religious, non-profit cooperatives or for-profit corporations. The first wave of independent schools after 1992 was primarily made up of special pedagogy schools, religious schools and parent cooperatives. After the early reform years, most new independent schools have been of a more general profile. This new type of independent schools, similar to the public schools in terms of educational profile, has increasingly gained market share and is now the most common type. School corporations started to establish themselves on the market in the late 1990s, and the number of schools run by such corporations has grown rapidly since then. The number of independent schools (with grade levels 7-9) has increased ten-fold since the reform, from 38 registered independent schools in 1993 to 396 in $2009 .^{8}$

Independent schools are required to be open to all students. They are not allowed to charge tuition fees on top of the voucher, and they cannot select pupils by ability or family background. If an independent school is oversubscribed, three selection criteria for admission are allowed: proximity to the school; waiting list (by date of application); and priority for children whose older siblings are already enrolled in the school.

The voucher reform also introduced choice between public schools, although maintaining priority for pupils residing close to the public school. Slots are first allocated to pupils within the public schools' catchment areas, after which pupils from other areas can be granted admission. Between 1992 and 2009, we approximate that the number of pupils opting out of their local school for a different public school has increased by 12 percentage points. ${ }^{9}$

\subsection{Theoretical background}

What are the determinants of school segregation and how do they relate to school choice as implemented in Sweden? Jenkins et al. (2008) propose three main channels which give rise to segregation between schools: residential segregation, parental school choice and schools' selection of pupils. ${ }^{10}$

First, residential segregation gives rise to school segregation. In a school system where catchment areas determine school attendance, residential and school segregation will be closely interlinked. In such a system, it is also likely that parental choice is executed through choice of neighbourhood, and as such, neighbourhood segregation will to some degree reflect Tiebout choice (Tiebout 1956). In a fully choice-based school system, it also likely that residential segregation plays a role: parents might have preferences for letting their child attend a local school, and mobility costs might impede parents from choosing a school outside of their local neighbourhood.

\footnotetext{
${ }^{8}$ A small category of schools at the compulsory level is under a different regulation. These are three old boarding schools (Gränna, Lundsberg and Sigtuna) that charge fees on top of the voucher. We exclude pupils in these schools from our analysis.

${ }^{9}$ See Section 3.2 and Appendix 1 for details on the approximation and on the evolution of public school choice over time.

${ }^{10}$ For a survey of the theoretical work on how the introduction of an overall voucher system impacts inequality and segregation, see Nechyba (2006). For theoretical work on the impact of different choice models, see Epple and Romano (2008), MacLeod and Urquiola (2009) and Barseghyan et al. (2014).
} 
Second, conditional on the choice of residence, school choice opportunities can affect school segregation through two different mechanisms, working in opposite directions. Segregation is likely to increase because families differ in their abilities to choose and in their preferences for what constitutes a good school. Parents that are better informed and have the resources to act on their preferred choice of school for their children are likely to be found in schools of higher quality. Well-informed parents may be more likely to place their children on the waiting list to popular schools at an early stage, and this increases the chances of admission. ${ }^{11}$ Immigrant families might lack the networks and language skills that facilitate making an informed choice. They may also, for cultural or religious reasons, prefer independent schools with such profiles or schools with a high fraction of peers from their own group. Natives might also want to escape schools with a high fraction of immigrants. In fact, both theoretical and empirical evidence point to the importance of peer group characteristics for parental choice. MacLeod and Urquiola (2009) show theoretically that when parents value high achievement per se, and not schools' value added, peer group composition turns out to be crucial for parental choice. Evidence from Sweden indicates that parents' motives for choice of school are related to the demographic composition of their neighbourhood (Malmberg et al. 2014).

In contrast, school choice can also imply lower school segregation: it increases the possibility for students to opt out of low-performing schools in socially deprived neighbourhoods. In a system with complete residential segregation, we expect unrestricted choice to lower school segregation.

Third and finally, in a school system where schools can select their pupils, either directly by cream skimming (i.e. selecting students by ability or family background) or indirectly by tuition fees, school segregation will increase. This is the case for some types of non-public schools in school systems in many countries. In Sweden, neither public nor independent schools at the compulsory level are allowed to directly creamskim or to charge tuition fees. There is however scope for independent schools to influence the pool of applicants indirectly either by locating in areas with a demographic profile that correlates with high pupil achievement or by targeting information to specific groups of parents. Anecdotal evidence also indicates that independent schools do not always abide by the rules and reject low-performing students with disruptive behaviour (SVT 2013).

\section{Data and measurement of school choice and segregation}

\subsection{The data}

Our data set is based on registers administered by Statistics Sweden and includes all individuals who completed the 9th and final grade of compulsory school, normally at age 16, during 1988-2009. These pupils are linked to their parents and the data are merged with detailed demographic information and registers of completed education and annual earnings. Importantly, the data set provides information on the school

\footnotetext{
${ }^{11}$ The waiting list for an independent school in Sweden is typically open for children from the day they are born, which implies that small independent schools can be oversubscribed long before children start school.
} 
attended and the residential neighbourhood of each student (at the time of 9th grade attendance) as well as of the neighbourhood of the school. The school register contains information on all Swedish schools, which allows us to identify whether a school is public or independent. Henceforth, we use the term school cohort to denote the cohort of students that leaves 9 th grade in a certain year.

The choice reform was implemented in 1992 and the first school cohort that in theory was affected graduated from 9th grade in the spring of 1993. For data availability reasons however, we use 1993 as the last pre-reform cohort instead of 1992: our data for 1992 do not cover all of the (few) private schools that existed, but for 1993 we can base our segregation measures on all schools. Arguably, it is unlikely that pupils changed school in the last year of compulsory education, and 1993 therefore serves as a good observation for the pre-reform period. $^{12}$

\subsection{Measures of school choice}

Since the reform in 1992, parents and their children can choose to apply to the local public school, to another public school outside of the catchment area or to an independent school. We therefore construct two measures to capture the extent to which families make the choice of opting out from the assigned local public school: (i) the fraction of students attending an independent school ('independent choice'), and (ii) the fraction of students attending a different public school than the one typically attended by pupils in the local catchment area ('public choice'). The former measure is straightforward to calculate, but the latter measure requires some elaboration. The data do not identify catchment areas directly (i.e. the assigned school), and as an alternative we use information on local residential areas, so-called SAMS units (small areas for market statistics), and define the most common public school attended by pupils in a given SAMS ${ }^{13}$ If a pupil attends a different school than the typical one in the neighbourhood, we consider this choice to a public school. ${ }^{14}$ This measure of opting out to a public school will likely contain some measurement error and be overstated, because catchment areas of schools do not always overlap with SAMS-neighbourhoods. For a description of the development of school choice in Sweden, we refer to Appendix 1, Fig. 5.

\subsection{Segregation indicators}

We study segregation in four dimensions, focusing on migration and socioeconomic background. To measure migration background, we use indicators for whether the pupil is foreign-born or native; and whether the pupil has immigrant background (defined as being foreign-born or born to two foreign-born parents) or not. ${ }^{15}$ To measure socioeconomic segregation, we use indicators for whether parental earnings are above or below the median and whether parents' average

\footnotetext{
12 The results are robust also to using 1992 as the pre-reform observation.

13 A SAMS unit is a geographical neighbourhood developed to correspond to "real" physical neighbourhoods. On average, a SAMS unit has 1000 inhabitants, and there are around 9200 units in total.

${ }^{14}$ Arguably, for many families it is probably an active choice to stay in the assigned public school. For ease of exposition, we still refer to choice to a non-assigned public school as 'public choice'.

${ }^{15}$ We define foreign-born as being born outside of the Nordic countries.
} 
years of schooling are above or below the median, in each school cohort. We label these dimensions of segregation as follows: immigrant; immigrant background; parental income; and parental education.

When we focus on the national trend in school segregation over time, we use the national median as a cut-off when constructing our measures of segregation. In the regressions where we exploit between-municipality variation, we use the municipality median when constructing the corresponding measures.

\subsection{The overexposure segregation index}

There is a vast literature on the measurement of segregation and the desired properties of a segregation index. Common indices of segregation are categorized into measures of evenness and measures of exposure (see for example Massey and Denton 1988, for a survey). Our choice of segregation index, a measure of peer exposure, is very closely related to the so-called isolation index of segregation (Bell 1957). An advantageous feature of this measure is that we can easily, without simulations, account for the fact that with small units (in our case schools), a random allocation of students to units can imply a substantial amount of segregation, in particular if there is a minority group that constitutes a small share of the population (Carrington and Troske 1997). ${ }^{16}$

We use the measure of own-group overexposure and the technique to account for segregation under random allocation presented in Åslund and Nordström Skans (2009). ${ }^{17}$ Figure 6 in Appendix 2 shows that the segregation trends using this measure are similar to the trends using Carrington and Troske's (1997) index of systematic dissimilarity. The exposure measure is described in more detail in Appendix 2, while in this section we present the intuition behind it. The starting point is that the population is divided into two groups, for example immigrants and natives, and each individual is assigned a value equal to the fraction of schoolmates belonging to his/her own group. These individual fractions are then averaged over all students, regardless of which group they belong to, forming the average own-group exposure measure of school segregation, or $\bar{e}$, which is the average probability of a student being exposed to a schoolmate from his/her own group. In contrast, if students were allocated randomly to schools, the probability that a school mate belongs to a specific group is equal to the group's population share. An immigrant student's share of immigrant school mates will on average equal the fraction of immigrants in the population, and similarly, a native student's share of native school mates will on average equal the fraction of natives in the population. These population shares are used to calculate $e^{\text {-random }}$, which is the average expected own-group exposure under random allocation, or the average probability of a student being exposed to own-group school mates, if the students

\footnotetext{
${ }^{16}$ Carrington and Troske (1997) suggest a simulation-based method to account for segregation under random allocation. The method used in this paper offers a simple and straightforward solution to the same problem which does not require simulations. This is particularly useful in our setting as the simulation-based approach is computationally heavy when estimating segregation indices for 184 municipalities over several years.

${ }^{17}$ Empirical applications of similar exposure measures can be found in for example Hellerstein and Neumark (2008) and Åslund and Nordström Skans (2010). Nordström Skans and Åslund (2009) also apply the exposure measure to school segregation.
} 
are randomly allocated to schools. We relate actual own-group exposure to expected own-group exposure under random allocation in the following way:

$$
R=\frac{\bar{e}}{\bar{e}^{\text {random }}}
$$

$R$ is the own-group overexposure ratio (i.e. overexposure to own group relative to random allocation). The own-group overexposure ratio is interpreted as the probability of a student having a schoolmate belonging to his/her own group being $R$ times what it would have been had the allocation of students to schools been random. If there is no segregation i.e. the distribution of students from different groups across schools corresponds to the groups' population shares, $R=1$. If the average student has a $10 \%$ higher probability of having a schoolmate from the same group, compared to a situation where students are randomly allocated, we have that $R=1.10$.

To account for neighbourhood segregation, or in other words the school segregation we would observe if all pupils went to their assigned school, we adapt the measure of own-group overexposure at the neighbourhood level and focus on exposure to neighbours belonging to the same group. Neighbours are defined as other students in the same school cohort, living in the same residential neighbourhood defined by catchment areas. Catchment areas are formed by grouping all SAMS-neighbourhood units whose pupils are assigned to the same public school (see Section 3.2 for more details on SAMS-units). More specifically, for each SAMS-unit we define the most common public school, and the units whose most common public school is the same form a catchment area. We have approximately 9200 SAMS-areas and they are grouped to form about 930 catchment areas (1992), which correspond approximately to the number of public schools. ${ }^{18}$

Finally, we are interested in whether independent schools are located in more or less advantaged areas, and whether we should expect their location patterns to affect school segregation in the hypothetical case that the schools admitted only pupils from the local neighbourhood. We estimate the expected exposure that we would observe if independent school students had the average characteristics of the SAMS-neighbourhood in which the school is located and relate this to exposure under random allocation i.e. the group share population mean. ${ }^{19}$ This is a hypothetical exercise where we attribute neighbourhood characteristics to the independent school student population, in order to understand whether it is schools' choice of location that potentially increases school segregation, as opposed to parental choice.

The exposure measure has the nice feature of having an intuitive meaning as it measures the extent to which members of different groups meet each other and interact in school. However, it does not fulfil all the desired properties of a segregation index (see Hutchens 2004 and Allen and Vignoles 2007, for discussions). In particular, it does not fulfil the property of scale invariance, which implies invariance to relative changes

\footnotetext{
${ }^{18}$ For SAMS-units with less than ten students, we use observations over three grade cohorts to determine the most common public school. The number of catchment areas is determined separately by year and increases over time, as the number of public schools increases.

${ }^{19}$ Independent schools do not have catchment areas in the strict meaning, but we can assume that students living close to the school are more likely to enrol.
} 
in group proportions. For example, if the share of immigrant students increases over time, exposure to immigrants will increase, while a segregation index based on the concept of evenness, such as the dissimilarity index, will remain constant as long as the inflow of immigrants does not alter each school's share of the total immigrant student population. In our setting, we study segregation over a period of 20 years and immigrant shares vary over the time period, which is likely to affect the exposure measure. But since we use $\mathrm{R}$ and relate peer exposure to expected exposure given group shares, we are able to control for such variations. Thus, by using $\mathrm{R}$, we overcome the potential issue of scale invariance.

A final complication related to measures of segregation is that the level of segregation depends on the size of the units over which we estimate segregation. School segregation is lower if a large school serves many neighbourhoods with varying demographics, and higher if each neighbourhood has its own school with a local catchment area. ${ }^{20}$ Over the time period that we study, the number of schools has increased both because of the establishment of a new sector of independent schools where the typical school is small, and because there has been a trend towards smaller public schools with a closer attachment to the local community. For a given nonrandom allocation of families to residential areas, an increase in the number of schools might therefore in itself raise school segregation. Our analysis accounts for this by controlling for catchment area segregation in each year: when the number of public schools increases, so does the number of catchment areas. ${ }^{21}$

\section{School segregation and school choice in Sweden}

\subsection{Trends in school segregation}

In Fig. 1, we start by documenting the segregation between schools over time, by pupils' migration and socioeconomic background. The solid lines correspond to owngroup overexposure relative to expected exposure under random allocation $(R)$. The yaxes show overexposure ratios, meaning that the scale is interpretable as the additional probability for an average student of having a schoolmate belonging to the same group: 1.10 means that the likelihood is $10 \%$ higher compared to what would be the case if the groups were allocated randomly. We note that two out of the four indicators show increased school segregation throughout the period 1988-2009: parental education and immigrant background. School segregation with respect to parental income and immigrant status appear to fluctuate some over time: segregation by parental income first decreases and then increases from the late 1990s and onward; and segregation by immigrant status peaks around 2000.

Comparing the levels in the four figures, we find that segregation measured as owngroup overexposure is initially highest with respect to parental income and education, where the probability of a student having high/low income/education parents was 1.04

\footnotetext{
${ }^{20}$ This is the so-called modifiable areal unit problem (MAUP). Its consequences for segregation indexes are discussed in Wong (1997).

${ }^{21}$ Our results are also robust to including a control for the change in number of schools over time.
} 

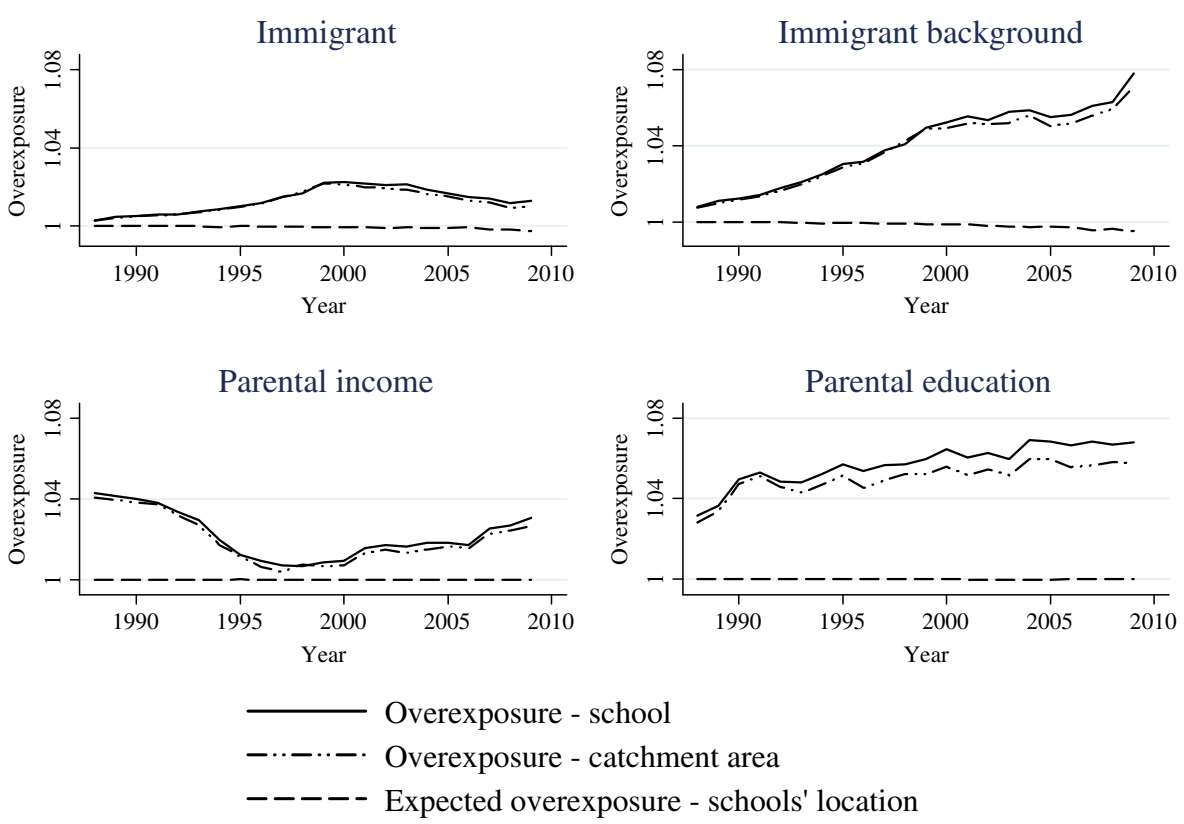

Fig. 1 School and neighbourhood segregation. Notes: The solid lines show own-group overexposure relative to random allocation in schools. The dot-dashed lines show own-group overexposure relative to random allocation in neighbourhoods, defined as catchment areas. The dashed lines show expected overexposure due to independent schools' locations. Calculations are based on the full population of each school cohort completing compulsory school

times the expected probability in 1988. For immigrant status and immigrant background, we see surprisingly little segregation in the beginning of the period.

In Fig. 1, we also document the development of neighbourhood own-group overexposure over time for the various categories of segregation (dash-dotted line), and the overexposure we should expect given independent schools' location patterns (dashed line). Neighbourhoods are here defined as catchment areas, and differences between school and neighbourhood segregation most likely occur because pupils opt out of the assigned school in their neighbourhood to attend a different school, either public or independent. We should interpret this difference as the additional school segregation that is related to the choice to opt out, over and above the neighbourhood segregation that may in part be due to school choice through Tiebout sorting.

First, we note that in the beginning of the period, before the school choice reform was enacted, segregation between attended schools and segregation between assigned schools (i.e. neighbourhoods defined by catchment areas) is identical. This is intuitive since it was very rare that pupils opted out from the assigned school. From the mid 1990s and onwards, actual school segregation by parental education lies somewhat higher than the segregation we should expect if all pupils attended the assigned school. Similarly, from 2000 and onwards, school segregation by immigrant background is slightly higher than what we would expect given catchment areas. From Fig. 1 it is thus clear that neighbourhood segregation (including Tiebout choice) plays an important role for school segregation throughout the period - but the figure also shows that after the option to opt out was introduced, school segregation is in some dimensions slightly 
higher than neighbourhood segregation. For example, in the 2009 grade cohort, students are $6 \%$ more likely to have a student from his/her own parental education group living in the same catchment area, compared to a random allocation of students across catchment areas, whereas they are $7 \%$ more likely to have a schoolmate from the same education group, compared to random allocation of students across schools.

Second, we focus on independent schools' locations. Figure 1 reveals that if the composition of pupils in independent schools would correspond to the composition in the neighbourhood where the school is located, school segregation at the aggregate level would not be affected by much. The expected exposure given by independent schools' locations is very close to the exposure under random allocation, and as such, the overexposure ratio is close to one. At the end of the period, independent schools' locations would contribute marginally to lower segregation between immigrants and natives, and between pupils of immigrant/Swedish background, if the pupils in the neighbourhood were proportionally represented in the school. This result is expected, given that independent schools have been established primarily in large cities and suburban areas, where the immigrant population is larger than in the rest of the country. It therefore seems unlikely that the overall trend in school segregation should be attributed to endogenous location of independent schools.

\subsection{School segregation in regions with varying degrees of school choice}

Figure 2 presents the trends in school choice in four different groups of high-to-low choice municipalities. School choice is here measured as the share of all pupils that opt out from their assigned public school, whether to independent alternatives or to other public schools. The municipalities are grouped in quartiles by the degree of school choice in 2009. The vertical axis shows the proportion of pupils that chose to opt out in a specific year. We note that manifested choice differs greatly across municipalities. The share has barely changed in some municipalities, whereas it has tripled (increased from 20 to $60 \%$ ) in the municipalities with most choice in $2009 .^{22}$

Some of this variation is likely due to demand for schools that are alternative to the assigned public schools, but the variation also reflects that choice opportunities to a great extent differ between municipalities even today. In many rural municipalities, choice is in practice almost as restricted as before the reform, because they lack independent schools (roughly half of the municipalities) and because the second closest public school is located very far away. In other municipalities, mainly the larger cities and their surroundings, there is basically unrestricted choice.

In Fig. 3, we relate school segregation trends to the change in school choice, by plotting overexposure in the four groups of municipalities characterized by different degrees of choice in 2009 (see Fig. 2). Not surprisingly, the levels of segregation differed in the four municipality groups already in the pre-reform period (1988-1992). This reflects that segregation in general is higher in urban municipalities, and these are also the municipalities where school choice has grown the most. Figure 3 also shows that in some dimensions, we see diverging segregation trends between groups of municipalities. This is most notably the case for segregation with respect to immigrant background, where overexposure has increased at a much higher rate in high-choice

$\overline{22}$ Notably, around $50 \%$ of the population can be found in the top quartile of municipalities. 


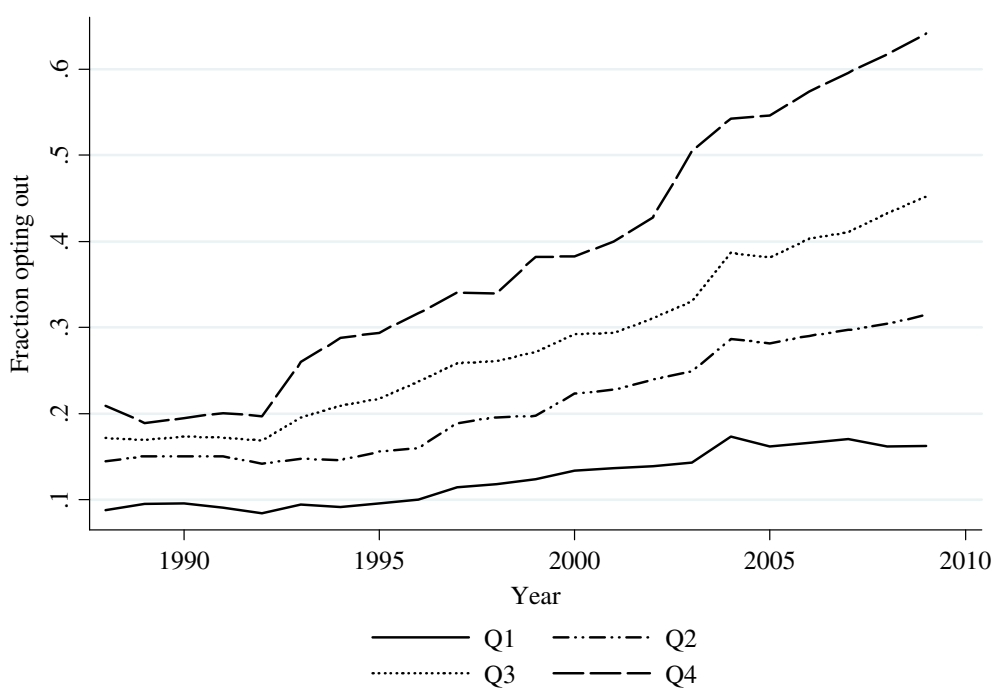

Fig. 2 School choice in high-to-low choice municipalities. Note: The figure is based on 184 municipalities i.e. the estimation sample. School choice refers to the fraction of pupils opting out from their assigned school to an independent or a non-assigned public school. The municipalities are divided into four groups, ranging from the quartile of municipalities with most choice in 2009 (Q4) to the quarter of municipalities with least choice in 2009, (Q1)

municipalities compared to low-choice municipalities. Overexposure with respect to immigrant status and parental education has also increased slightly more in high-choice
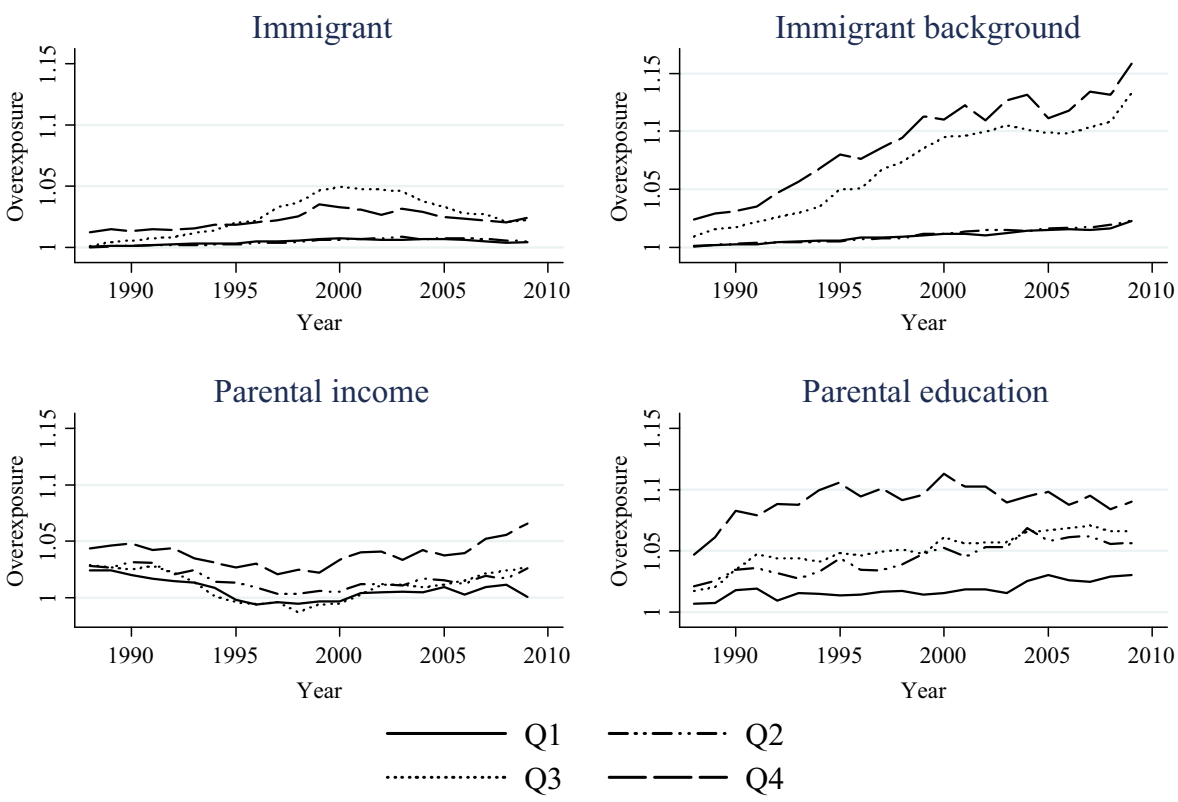

Fig. 3 School segregation in high-to-low choice municipalities. Note: The figures show own-group overexposure relative to random allocation. The figure is based on 184 municipalities i.e. the estimation sample. The municipalities are divided into four groups, ranging from the quartile of municipalities with most choice in 2009 (Q4) to the quarter of municipalities with least choice in 2009, (Q1) 
municipalities, even though the pattern is much less clear. For all four segregation indicators, school segregation has remained relatively constant in low-choice municipalities.

As we have seen in Fig. 1, actual school segregation closely follows the segregation predicted by pupils' assigned school. To what extent can neighbourhood segregation account for the diverging trends for different municipality types, presented in Fig. 3? To shed light on this issue, Fig. 4 plots the difference between actual school segregation and assigned school segregation in the four groups of municipalities. ${ }^{23}$ We find that in municipalities with little manifested school choice, there is virtually no difference between segregation measured between actual schools and assigned schools (i.e. catchment areas). It is notable, however, that in the two groups of municipalities where choice has increased the most, school segregation has increased more than we should expect given residential patterns in three out of four cases: between immigrants and natives; between pupils with immigrant/Swedish background and between pupils with high vs. low parental education.

This graphical evidence summarizes the main results of this study: after accounting for residential segregation, school segregation has increased more in municipalities where school choice has become more prevalent. To further check the robustness of this empirical correlation, the next section presents a regression analysis at the municipality level, in which school segregation is regressed on school choice, neighbourhood 'catchment area' segregation and expected segregation due to independent schools' locations, and where we account for time-invariant municipality specific characteristics, as well as pre-reform demographics in the municipalities.

\section{Regressions of school segregation on school choice}

\subsection{Empirical framework}

We now extend the graphical analysis and run regressions at the municipality (i.e. school district) level. ${ }^{24}$ We separate school choice into two measures; choice to independent schools, and choice to non-assigned public schools, and run multivariate linear regression models where we control for neighbourhood ('catchment area') overexposure and expected exposure due to independent schools' location decisions. The purpose of the regression analysis is to shed light on the relative contributions of the different underlying causes for school segregation, and in particular to establish whether the correlation between school choice and school segregation remains after conditioning on neighbourhood segregation. We limit the analysis to municipalities with at least two schools throughout the period. This restriction implies that the number of municipalities drops from 284 to 184 i.e. we drop 100 of Sweden's municipalities. Notably, these are very small and constitute only $10 \%$ of the population. ${ }^{25}$

\footnotetext{
${ }^{23}$ This is equivalent to the difference between the solid and the dash-dotted line in Figure 1 , but the differences in Table 6 are calculated separately for each of the four groups of municipalities characterized by different levels of choice.

${ }^{24}$ We use the pre-reform (1991) regional structure, implying 284 municipalities.

${ }^{25}$ We also exclude very small schools, with less than ten pupils.
} 

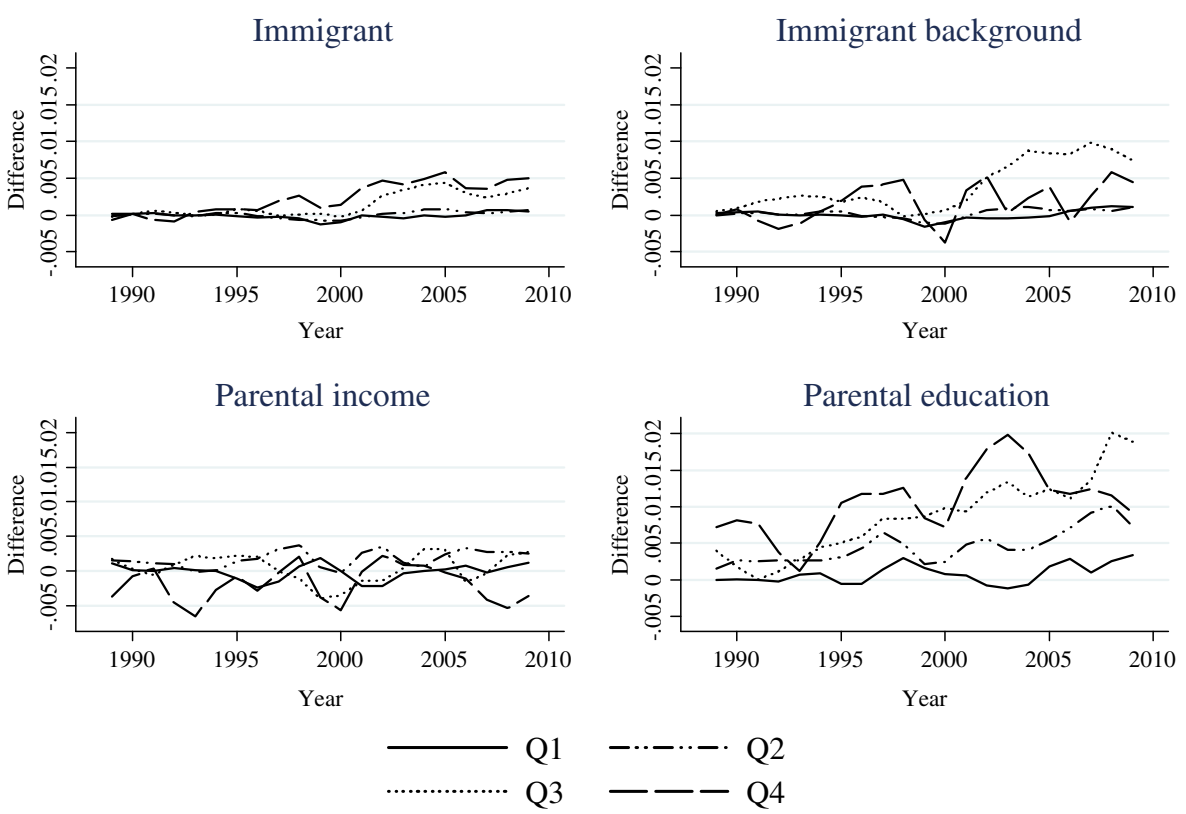

Fig. 4 Difference between school segregation and neighbourhood segregation in high-to-low choice municipalities. Note: The figures show the differences between own-group overexposure relative to random allocation in schools and in neighbourhoods (defined as catchment areas). The figure is based on 184 municipalities i.e. the estimation sample. The municipalities are divided into four groups, ranging from the quartile of municipalities with most choice in 2009 (Q4) to the quarter of municipalities with least choice in 2009, (Q1)

Our empirical approach is to exploit the variation in the expansion of school choice across municipalities since the reform in 1992. In order to control for unobserved differences between municipalities and to capture long-term consequences of increased choice we estimate the following model $^{26}$ :

$$
\Delta R_{m}^{s}=c+\beta_{1} \Delta \text { IndepChoice }_{m}+\beta_{2} \Delta \text { PubChoice }_{m}+\gamma_{1} \Delta R_{m}^{n}+\gamma_{2} \Delta R_{m}^{i}
$$

\footnotetext{
${ }^{26}$ An alternative specification is to use year-to-year variation in a municipality panel over all years $1993-$ 2009 , including year and municipality-fixed effects. The main reason for choosing the change-change specification is because we want to give some time for the school choice variables to affect school segregation. There are three motivations for this: First, we only have access to segregation measures based on characteristics for the population of students at grade 9 (the last grade of compulsory school), as information about which school a pupil attended in grade 1-8 is not available from Swedish registers until very recently. However, the choice of school typically takes place the year before 1st grade, 4th grade or 7th grade (which divides the three levels of compulsory schooling). Second, it takes time for independent schools to start and for families to choose. This is evident from the slow increase in the fraction of pupils attending an independent school in Figure 5 (Appendix 1). About 8 years after the reform, the fraction students graduating 9th grade from an independent school was still only around $3 \%$. In addition, we do not want to capture only a mechanical correlation from year-to-year variations in the fraction of pupils opting out but also changes in preferences and attitudes that might be associated with the possibility to opt out, and that might change more slowly. Third, we also wanted to facilitate comparison with Böhlmark and Lindahl (2015), who analyzed the impact of independent school choice on student achievement. The same change specification is also used in Hsieh and Urquiola (2006) for Chile. Nevertheless, the results from a fixed effects specification are very close to our preferred specification, and are reported in Appendix 3.
} 
where $\Delta R_{m}^{s}$ denotes the change in school segregation relative to random allocation (measured by the overexposure ratio) between 1993 and 2009 for 9th grade pupils attending a school in municipality $m$ in those years; $\Delta$ IndepChoice $_{m}$ denotes the change in the share of independent school students in municipality $m$ between 1993 and 2009; $\Delta$ PubChoice $_{m}$ denotes the change in the share of students opting for a nonassigned public school in municipality $m$ between 1993 and 2009; and $\Delta R_{m}^{n}$ and $\Delta R_{m}^{i}$ denote the changes in neighbourhood segregation and the segregation expected by independent schools' location, respectively. ${ }^{27}$ The parameters $\beta_{1}$ and $\beta_{2}$ capture how an increase in choice from 0 to $100 \%$ is associated with school segregation, measured as the own-group overexposure ratio (relative to random allocation). We abstract from causal interpretations of the parameters $\beta_{1}$ and $\beta_{2}$ and view these parameters as providing conditional associations.

\subsection{Descriptive statistics}

Table 1 presents descriptive statistics of the municipality level data used in the regressions. While Fig. 1 displays the national trends including all schools and municipalities weighted by the number of students, the data in Table 1 present our sample of 184 municipalities, where each municipality is given equal weight. For this reason, the segregation averages in Fig. 1 and Table 1 will not necessarily correspond to each other.

Statistics for the two school choice variables are listed in the first panel of Table 1 and are shown for the school cohorts 1993 and 2009 and for the change between these 2 years. The last column shows $p$ - values from tests of equality of the means in 1993 and 2009. As no independent voucher-type schools existed prior to the school choice reforms, the share of independent school students was zero before 1993, and very small the first year after the reform (1993). The average growth in the share of independent school students has been about $5.7 \%$ up to $2009 .{ }^{28}$ The 'public choice' variable is an approximation of the share of pupils opting out from the assigned school to a different public school. A fairly large fraction of students, $12.6 \%$, opted out to another public school before the reform. We see that the average growth in public choice is about 8.6 percentage points i.e. the share of students that opted out to a non-assigned public school almost doubled between 1993 and 2009. ${ }^{29}$ This variable is likely estimated with error (see Section 3.2.) because we can only approximately define catchment areas. However, if we make the assumption that measurement error is constant over time within municipalities, the difference over time will not be measured with error and is informative about the growth of public school choice.

In the second to fourth panels of Table 1, we show summary statistics for the four indicators of segregation. We confirm that school segregation has increased and note that there is considerable variation across municipalities in this regard. ${ }^{30}$

\footnotetext{
${ }^{27}$ Note that the index $R_{m}$ is based on a pupil-weighted mean, whereas we give equal weight to municipalities in the regressions.

${ }^{28}$ This number is lower than the national growth because each municipality is given equal weight and larger municipalities have more independent school students.

${ }^{29}$ See Appendix 1 for a more detailed description of the evolution of school choice since the reform for the population of students.

${ }^{30}$ The sample used in analyzing immigrants-natives consists of 181 municipalities. The reason is that in three municipalities we do not observe any immigrant students in the 9th grade in 1993.
} 
Table 1 Descriptive statistics

\begin{tabular}{llll}
\hline 1993 & 2009 & Diff 2009-1993 & $t$ test of H0:Diff $=0$ \\
Mean (std. dev.) & Mean (std. dev.) & Mean (std. dev.) & $p$ value \\
\hline
\end{tabular}

School choice variables

Share indep. choice

$\begin{array}{llll}0.001 & 0.058 & 0.057 & 0.000 \\ (0.006) & (0.083) & (0.082) & \\ 0.126 & 0.212 & 0.086 & 0.000 \\ (0.072) & (0.105) & (0.080) & \end{array}$

School overexposure

Parents' education

$$
1.014
$$

1.021

0.008

0.000

Parents' income$$
\text { (0.030) }
$$

(0.025)

Parents income

1.016

1.022

0.006

0.629

Foreign/native born

(0.027)

(0.040)

(0.036)

$\begin{array}{ll} & (0.006) \\ \text { Immigrant background } & 1.005 \\ & (0.018)\end{array}$

1.005

0.003

0.000

(0.009)

$(0.011)$

0.022

0.000

Neighbourhood-catchment area-overexposure

Parents' education

1.021
$(0.023)$

Parents' income

1.019

(0.021)

Foreign/native born

1.002

(0.005)

Immigrant background

1.005
$(0.015)$

Expected overexposure by schools' locations

$$
\text { Parents' education }
$$

$$
1.000
$$$$
\text { (0.001) }
$$

Parents' income

1.000

(0.000)

Foreign/native born

1.000

(0.001)

Immigrant background

1.000
$(0.001)$

(0.001)

(0.064)

(0.051)

$\begin{array}{lll}1.019 & -0.001 & 0.961 \\ (0.027) & (0.027) & \\ 1.018 & -0.001 & 0.503 \\ (0.019) & (0.018) & \\ 1.003 & 0.001 & 0.002 \\ (0.006) & (0.005) & \\ 1.019 & 0.014 & 0.000 \\ (0.047) & (0.035) & \end{array}$

1.002

0.002

0.000

(0.007)

(0.008)

0.002

0.000

(0.009)

(0.009)

0.999

$-0.001$

0.025

(0.007)

0.999

(0.011)

(0.007)

$-0.001$

0.107

(0.011)

Municipality demographics

Number of students

456

(522)

565

(798)

109

0.000

Fathers' schooling

11.15

11.62

(0.58)

Mothers'schooling

11.31

(0.45)

Parents' log income
(0.50)

12.19

(0.40)

12.21
(295)

0.47

0.000

(0.24)

0.88

0.000

(0.24)

0.36

0.000 
Table 1 (continued)

\begin{tabular}{lllll}
\hline & $\begin{array}{l}2009 \\
\text { Mean (std. dev.) }\end{array}$ & $\begin{array}{l}\text { Diff 2009-1993 } t \text { test of H0:Diff=0 } \\
\text { Mean (std. dev.) }\end{array}$ & $\begin{array}{l}\text { Mean (std. dev.) } \\
p \text { value }\end{array}$ \\
\hline \multirow{2}{*}{ Fraction immigrant backgr. } & 0.06 & $(0.17)$ & $(0.10)$ \\
& $(0.16)$ & 0.10 & 0.04 & 0.000 \\
Fraction immigrant & 0.04 & $(0.08)$ & $(0.04)$ & 0.005 \\
Nr of observations & $(0.03)$ & 0.05 & 0.005 & \\
\hline
\end{tabular}

The last panel of Table 1 shows summary statistics for the municipality characteristics that we use in our estimations to adjust for differences among municipalities before the school choice reforms. All of the variables based on students' own or family characteristics are aggregated to the municipality-year level by school cohort and are based on the same students that are used to calculate the school choice and segregation measures.

\subsection{Results}

We now turn to estimation of Eq. (2) i.e. we investigate whether increased school segregation is associated with parental school choice, neighbourhood segregation and/ or segregation due to independent schools' locations. For each outcome, we present seven specifications. We start by showing results from simple specifications that exclude all controls and as such report the unconditional association between a change in segregation and a change in our measure of interest. In tables 2, 3, 4 and 5 we look at the association between school segregation and total school choice (column 1), independent school choice and public school choice (column 2), neighbourhood overexposure (column 3) and expected overexposure given independent school location (column 4). In columns 5-7, we show estimates from multivariate regressions where we include all four predictors simultaneously, without other controls (column 5), and with controls for a number of municipality characteristics (listed in Table 1) measured prior to the choice reforms (column 6) and with additional controls for the change in these municipality characteristics between 1993 and 2009 (column 7).

First, we focus on the results for immigrants versus natives (Table 2, for immigrant status, and Table 3, for immigrant background). We see that in column 1, there is a positive and statistically significant association between own-group overexposure i.e. school segregation, and school choice. An increase in total choice with 10 percentage points is associated with an increase in own-group-overexposure in the immigrant/ native dimension with 0.002 (Table 2). As a point of comparison, the average prereform own-group overexposure in the municipality sample was 1.002 (see Table 1). This implies a shift from a $0.2 \%$ higher probability to meet a pupil from one's own group, compared to the population mean, to a $0.4 \%$ higher probability, compared to the population mean. The corresponding estimate in Table 3 implies a much larger association: an increase by 10 percentage points in the share of students opting out is related to an increase in the probability to meet a student from one's own group by 
Table 2 First difference model of change in school segregation between immigrants and natives

$\Delta$ Own-group overexposure: immigrant/native

(2)

(3)

(4)

(5)

(6)

(7)

$\Delta$ Share total choice

0.018

$(0.006)^{* *}$

$\Delta$ Share indep. school choice

$\Delta$ Share public school choice

$\Delta$ Neighbourhood

overexposure

$\Delta$ Expected exposure by location

Observations

R-squared

Demographic controls 1993

$\Delta$ Demographic controls

\subsection{0}

$(0.014)^{*}$

0.005

(0.009)

181

0.07

181
0.09

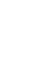

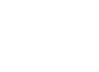

\begin{tabular}{llll} 
& 0.033 & 0.037 & 0.029 \\
& $(0.013)^{* *}$ & $(0.014)^{* *}$ & $(0.012)^{*}$ \\
& 0.004 & 0.009 & 0.010 \\
& $(0.008)$ & $(0.008)$ & $(0.007)$ \\
& 0.173 & 0.173 & 0.152 \\
& $(0.041)^{* *}$ & $(0.043)^{* *}$ & $(0.040)^{* *}$ \\
0.395 & 0.462 & 0.438 & 0.380 \\
$(0.196)^{*}$ & $(0.179)^{*}$ & $(0.181)^{*}$ & $(0.142)^{* *}$ \\
181 & 181 & 181 & 181 \\
0.09 & 0.35 & 0.40 & 0.53 \\
& & $\mathrm{x}$ & $\mathrm{x}$ \\
& & & $\mathrm{x}$ \\
\hline
\end{tabular}

Note: First difference OLS regressions of the change (2009-1993) in own-group overexposure on the change in the total fraction of pupils opting out (total choice) and the fractions opting out to independent and publics schools (indep. choice and public choice), and on changes in neighbourhood overexposure and expected overexposure given by schools' locations. Demographic controls in 1993 are listed in Table 1. Robust standard errors in parentheses

+ significant at $10 \% *$ significant at $5 \% ; *$ significant at $1 \%$

0.012. In column 2, it becomes clear that these positive associations should be attributed entirely to independent school choice.

Column 3 shows that neighbourhood ('catchment area') overexposure is strongly associated with school segregation, in particular in terms of immigrant background for which both the coefficient and the R-squared are high. In column 4, we find that there is a positive association between school segregation and expected segregation given independent schools' locations. Expected overexposure due to schools' locations has decreased (see Table 1) because independent schools have been established in big cities and suburban areas, where the immigrant population is larger compared to the rest of the country. The estimated associations thus imply that in municipalities where independent schools locate in areas with high proportions of immigrant students, school segregation tend to be lower. However, the establishment patterns imply very small changes in expected overexposure and contribute only to marginal changes in school segregation. ${ }^{31}$

The next column includes the four variables simultaneously, and shows that the association between independent school choice and segregation by immigrant background is largely driven by residential segregation patterns: it drops from 0.20 to 0.05 , but remains statistically significant as precision is improved when adding covariates to

\footnotetext{
${ }^{31}$ The associations in Tables 2 and 3, and the decline in expected overexposure given by schools' locations in Table 1, indicate that we would expect own-group overexposure to decrease by 0.0004 and 0.0018 , respectively.
} 
Table 3 First difference model of change in school segregation between pupils of immigrant/Swedish background

$\Delta$ Own-group overexposure: immigrant background/Swedish background

$(1)$

(2)

(3)

(4)

(5)

(6)

(7)

\begin{tabular}{|c|c|c|c|c|c|c|c|}
\hline$\Delta$ Share total choice & $\begin{array}{l}0.118 \\
(0.034)^{* *}\end{array}$ & & & & & & \\
\hline \multirow[t]{2}{*}{$\Delta$ Share indep. school choice } & & 0.202 & & & 0.054 & 0.070 & 0.061 \\
\hline & & $(0.078)^{*}$ & & & $(0.025)^{*}$ & $(0.032)^{*}$ & $(0.028)^{*}$ \\
\hline \multirow[t]{2}{*}{$\Delta$ Share public school choice } & & 0.031 & & & -0.003 & 0.002 & 0.001 \\
\hline & & $(0.039)$ & & & $(0.017)$ & $(0.017)$ & $(0.017)$ \\
\hline \multirow{2}{*}{$\begin{array}{l}\Delta \text { Neighbourhood } \\
\text { overexposure }\end{array}$} & & & 0.945 & & 0.872 & 0.813 & 0.765 \\
\hline & & & $(0.067)^{* *}$ & & $(0.050)^{* *}$ & $(0.061)^{* *}$ & $(0.070)^{* *}$ \\
\hline \multirow{2}{*}{$\begin{array}{l}\Delta \text { Expected exposure by } \\
\quad \text { location }\end{array}$} & & & & 1.776 & 0.610 & 0.609 & 0.563 \\
\hline & & & & $(0.756)^{*}$ & $(0.261)^{*}$ & $(0.279)^{*}$ & $(0.239)^{*}$ \\
\hline Observations & 181 & 181 & 181 & 181 & 181 & 181 & 181 \\
\hline R-squared & 0.10 & 0.12 & 0.84 & 0.14 & 0.85 & 0.87 & 0.89 \\
\hline Demographic controls 1993 & & & & & & $\mathrm{x}$ & $\mathrm{x}$ \\
\hline$\Delta$ Demographic controls & & & & & & & $\mathrm{x}$ \\
\hline
\end{tabular}

Note: See Table 2

the model. The point estimate for school segregation between immigrants and natives is not as sensitive and remains fairly constant after accounting for catchment area segregation. The estimates are also largely unaffected when pre-reform levels of municipality demographics are controlled for, as in column 6, and when we also include controls for changes in these municipality characteristics (column 7).

The overall impression from the results presented in Tables 2 and 3 is that the associations between independent school choice and school segregation are qualitatively robust across specifications and that the estimates remain statistically significant also when accounting for neighbourhood segregation. This result corresponds well to what we found in Fig. 4. For immigrants/natives, the conditional OLS estimate in Table 2, column 6, is 0.037. To gain further understanding of the magnitude of this estimate, we can scale it in terms of standard deviations and conclude that the predicted change given the average increase in independent choice $(0.037 * 0.057)$ corresponds to 0.35 of a standard deviation in the 1993 municipality distribution of school segregation for immigrants/natives. If we do a similar calculation for immigrant/Swedish background, we find that the estimate 0.070 (column 6 of Table 3 ) corresponds to $22 \%$ of a standard deviation in the 1993 municipality distribution of school segregation for immigrant/Swedish background.

Alternatively, we can relate the estimates to the overall growth in school segregation in our sample. Let us focus on immigrant/Swedish background which (as can be seen from the solid line in Fig. 1) has a clear upward trend during the period. The average increase between 1993 and 2009 in our municipality level data amounts to 0.022 (see Table 1$)$ : the change predicted by independent choice $(0.070 * 0.057)$ is thus associated 
with about $18 \%$ of the change in school segregation over time. ${ }^{32}$ These estimates imply that students of immigrant/Swedish background have moved from being 0.5 to $0.9 \%$ more likely to meet a schoolmate of their own group, compared to what would be the case if pupils were allocated randomly.

The results also lend further support to the graphical analysis which showed that school segregation largely follows patterns of residential segregation, also in the postreform period when choice may be exercised. Unconditional associations (in our first difference model) indicate that residential segregation explains $18 \%$ of the variation in school segregation between immigrants and natives, and $84 \%$ of the variation in school segregation between pupils of immigrant/Swedish background. ${ }^{33}$ Changes in school choice, however, explain between 9 and $12 \%$ of the variation, while the expected overexposure by independent schools' location patterns explains between 9 and $14 \%$.

If we relate the conditional estimates in column 6 of Table 3 to overall growth in school segregation in our sample, we find that residential neighbourhood segregation explains $50 \%$ of the increase in school segregation between pupils of immigrant/Swedish background. As we mentioned above, the contribution from independent school choice was $18 \%$. As the estimate for public school choice is statistically insignificant, so is its contribution to the change during the period. For independent schools' location pattern, we find that it possibly reversed the growth in school segregation somewhat. ${ }^{34}$

Next, we focus on the results for segregation by socioeconomic background (Table 4, for parental income, and Table 5, for parental education). Again, we see that in column 1, there is a positive and statistically significant association between own-group overexposure i.e. school segregation and school choice. From column 2 and onwards, separating overall school choice into independent school choice and public school choice, it is clear that results differ for parental income and education. For the former, independent school choice is more important, whereas for parental education, public school choice drives most of the association. We note that the estimate for independent school choice is sensitive to what other controls are included in the estimations. Similar to the findings in the previous tables, residential segregation is a strong predictor of school segregation with $\mathrm{R}$-squared in the range $0.28-0.50$. There is no association between school segregation and expected segregation given independent schools' locations for income, whereas there is a (marginally) positive association for education.

The remaining columns in Tables 4 and 5 (column 5 and onwards) show that the associations between school choice and school segregation are robust both to accounting for residential segregation, and to pre-reform municipality demographics. Notably, in the conditional models, segregation by parental education is associated with both public and private choice. The magnitude of the public choice estimate in column 6 ,

\footnotetext{
32 The fraction explained for segregation between immigrants/natives is much higher: $65 \%$. However, this can be a bit misleading as the increase in school segregation for immigrants/natives is small during the period.

${ }^{33} \mathrm{R}$-squared is lower when we study immigrant status because we have fewer immigrants in the data (compared to students with immigrant background) and for small municipalities this introduces noise in the measurement of school and neighbourhood segregation. When we limit the sample to the 90 largest municipalities, R-squared increases to 0.55 and the point estimates remain unchanged.

34 This change is only marginally significant $(p$ - value $=0.107)$ and the contribution is only about $3 \%$ [calculated as $(-0.001 * 0.610) / 0.022)$.
} 
Table 4 First difference model of change in school segregation between pupils of high/low parental income

$\Delta$ Own-group overexposure: high/low parental income

$\begin{array}{lllllll}(1) & (2) & (3) & (4) & (5) & \text { (6) } & \text { (7) }\end{array}$

\begin{tabular}{|c|c|c|c|c|c|c|c|}
\hline$\Delta$ Share total choice & $\begin{array}{l}0.068 \\
(0.020)^{* *}\end{array}$ & & & & & & \\
\hline$\Delta$ Share indep. school choice & & $\begin{array}{l}0.103 \\
(0.037)^{* *}\end{array}$ & & & $\begin{array}{l}0.040 \\
(0.026)\end{array}$ & $\begin{array}{l}0.072 \\
(0.027)^{* *}\end{array}$ & $\begin{array}{l}0.070 \\
(0.028)^{*}\end{array}$ \\
\hline$\Delta$ Share public school choice & & $\begin{array}{l}0.032 \\
(0.026)\end{array}$ & & & $\begin{array}{l}0.023 \\
(0.022)\end{array}$ & $\begin{array}{l}0.032 \\
(0.023)\end{array}$ & $\begin{array}{l}0.032 \\
(0.023)\end{array}$ \\
\hline $\begin{array}{l}\Delta \text { Neighbourhood } \\
\text { overexposure }\end{array}$ & & & $\begin{array}{l}0.541 \\
(0.052)^{* *}\end{array}$ & & $\begin{array}{l}0.513 \\
(0.053)^{* *}\end{array}$ & $\begin{array}{l}0.511 \\
(0.054)^{* *}\end{array}$ & $\begin{array}{l}0.517 \\
(0.053)^{* *}\end{array}$ \\
\hline $\begin{array}{l}\Delta \text { Expected exposure by } \\
\text { location }\end{array}$ & & & & $\begin{array}{l}-0.028 \\
(0.140)\end{array}$ & $\begin{array}{l}-0.119 \\
(0.211)\end{array}$ & $\begin{array}{l}-0.215 \\
(0.163)\end{array}$ & $\begin{array}{l}-0.214 \\
(0.157)\end{array}$ \\
\hline Observations & 184 & 184 & 184 & 184 & 184 & 184 & 184 \\
\hline R-squared & 0.09 & 0.11 & 0.50 & 0.00 & 0.52 & 0.57 & 0.58 \\
\hline $\begin{array}{l}\text { Demographic controls } 1993 \\
\Delta \text { Demographic controls }\end{array}$ & & & & & & $\mathrm{x}$ & $\begin{array}{l}\mathrm{x} \\
\mathrm{x}\end{array}$ \\
\hline
\end{tabular}

Note: See Table 2

Table 5 First difference model of change in school segregation between pupils of high/low parental education $\Delta$ Own-group overexposure: high/low parental education

\begin{tabular}{llllll}
\hline 1 & (1) & (3) & (4) & (5) & (6)
\end{tabular}

\begin{tabular}{|c|c|c|c|c|c|c|c|}
\hline$\Delta$ Share total choice & $\begin{array}{l}0.035 \\
(0.017)^{*}\end{array}$ & & & & & & \\
\hline$\Delta$ Share indep. school choice & & $\begin{array}{l}0.021 \\
(0.030)\end{array}$ & & & $\begin{array}{l}0.016 \\
(0.022)\end{array}$ & $\begin{array}{l}0.054 \\
(0.025)^{*}\end{array}$ & $\begin{array}{l}0.070 \\
(0.027)^{*}\end{array}$ \\
\hline$\Delta$ Share public school choice & & $\begin{array}{l}0.049 \\
(0.023)^{*}\end{array}$ & & & $\begin{array}{l}0.064 \\
(0.022)^{* *}\end{array}$ & $\begin{array}{l}0.082 \\
(0.022)^{* *}\end{array}$ & $\begin{array}{l}0.081 \\
(0.022)^{* *}\end{array}$ \\
\hline$\Delta$ Neighbourhood overexposure & & & $\begin{array}{l}0.407 \\
(0.074)^{* *}\end{array}$ & & $\begin{array}{l}0.422 \\
(0.069)^{* *}\end{array}$ & $\begin{array}{l}0.431 \\
(0.068)^{* *}\end{array}$ & $\begin{array}{l}0.464 \\
(0.062)^{* *}\end{array}$ \\
\hline $\begin{array}{l}\Delta \text { Expected exposure by } \\
\text { location }\end{array}$ & & & & $\begin{array}{l}0.215 \\
(0.149)\end{array}$ & $\begin{array}{l}0.277 \\
(0.143)+\end{array}$ & $\begin{array}{l}0.232 \\
(0.149)\end{array}$ & $\begin{array}{l}0.230 \\
(0.150)\end{array}$ \\
\hline Observations & 184 & 184 & 184 & 184 & 184 & 184 & 184 \\
\hline R-squared & 0.03 & 0.04 & 0.28 & 0.01 & 0.35 & 0.40 & 0.44 \\
\hline Demographic controls 1993 & & & & & & $\mathrm{x}$ & $\mathrm{x}$ \\
\hline$\Delta$ Demographic controls & & & & & & & $\mathrm{x}$ \\
\hline
\end{tabular}

Note: See Table 2 
Table 5, implies that the average ( 8.6 percentage point) increase in the fraction of students opting out to an alternative public school is associated with an additional probability to be exposed to a schoolmate from one's own group by $0.007 \%$, which corresponds to $25 \%$ of the standard deviation in the 1993 municipality distribution.

To sum up our key findings, we conclude that neighbourhood segregation is the most important contributor to school segregation, also in the post-reform period when school choice was in practice. It is likely that neighbourhood segregation to some degree reflects a form of Tiebout choice, where parents choose to locate in a certain area to get access to a particular school. However, our results show that the option for parents to execute school choice by opting out of the assigned school is associated with an increase in school segregation over and above the segregation we should expect by residential segregation patterns, including Tiebout choice.

An important question is then whether the estimates are large or small in magnitude? As we have described above, the estimates indicate that an average increase in parental choice is related to $65 \%$ of the overall increase in segregation between immigrants and natives, and $18 \%$ of the overall change between immigrant background and Swedish background pupils, but it is unclear whether we should regard the overall changes as large or small. To address this question, we turn to international evidence on school segregation based on PISA data. Schnepf (2004) shows that in a sample of ten western countries, school segregation between children of immigrant/native background, measured with the dissimilarity index, ranges from 0.4 (Switzerland) to above 0.6 (Canada, UK and the USA). In this sample Sweden lies somewhere in the middle of the distribution at 0.5. As a comparison, we estimate school segregation in the same dimension applying the dissimilarity index to our data, and find that school segregation between immigrants and natives has increased from 0.36 to 0.41 , and that the corresponding change between students of immigrant/Swedish background is 0.41 to 0.47 between 1993 and 2009. Under the assumption that school choice can explain 65 and $18 \%$ of these changes, respectively, the associations between school choice and segregation would imply relatively small shifts in the international distribution. Similarly, Sweden seems to still rank among the least segregated countries if we study segregation by social background. Jenkins et al. (2008) find that in a sample of 27 industrialized countries, a large majority of the countries have a dissimilarity index of school segregation between 0.3 and 0.4 , when comparing children of high/low family background. ${ }^{35}$ Although not fully comparable as we cannot define high/low family background in the same way as Jenkins et al., we adopt the dissimilarity index to our data and find that between 1993 and 2009 school segregation between high/low parental education increased from 0.23 to 0.25 . This is a relatively small change and Sweden would still rank among the least segregated countries in Jenkins et al.'s comparison. ${ }^{36}$ These international comparisons warrant some caution however: crosscountry variations in school segregation (both by ability and family background) at age 15 reflect institutional differences between school systems, such as early and late tracking, and it is not clear-cut which school systems are to be considered comparable. We can

\footnotetext{
$\overline{35}$ Jenkins et al. (2008) define high (low) family background by whether a parental occupation index is above (below) the national median.

${ }^{36}$ Note that here we refer to the unadjusted dissimilarity index, while we in Appendix Figure 6 show the index of systematic dissimilarity.
} 
nevertheless conclude that the estimated associations between school choice and school segregation in Sweden do not imply a shift to dramatically higher levels of segregation. ${ }^{37}$

\subsection{Further sensitivity analysis}

Our measures of choice capture the fractions of students that opt out from their assigned schools. In a sensitivity analysis, we make use of municipality variation in the fraction of independent schools (as opposed to the fraction of independent school students), and in the Herfindahl index, as alternative measures of choice. ${ }^{38}$ These alternative measures of choice exploit a similar but slightly different type of variation compared to our earlier choice measures. The fraction of independent schools captures the establishment of new schools in the market, net of the actual enrolment of students. The Herfindahl index (here based on public schools' market shares only) is an index of the degree of competition in the market and captures whether there are only very few or many schools available to choose among in a given municipality. We fix the Herfindahl index at 1 (i.e. no competition and no choice) in the pre-reform period and exploit the change over time in the choice opportunities that relate to the number of public schools (and school sizes) in each municipality. In Table 6, we show that the associations between school choice and school segregation are qualitatively robust also when we use these alternative measures of choice. In order to compare the size of these estimates to those presented earlier, we have calculated standardized coefficient estimates of both baseline estimates and the estimates presented in Table 6 (not shown). The effect sizes from the sensitivity analysis are in most cases about $30 \%$ smaller for independent choice and similar or slightly larger for public choice. The key message from this sensitivity analysis is therefore that the associations between school choice and school segregation are robust also to using alternative measures of school choice.

In an additional sensitivity analysis, we assess the potential risk of bias due to measurement error in the assignment of pupils to catchment areas (i.e. neighbourhoods). According to our public school choice measure, $14 \%$ of all pupils attended a public school outside the catchment area before the choice reforms (see Fig. 5). This in part reflects a possibility to deviate from assigned catchment areas already before the reform, but it also reflects measurement error in our assignment of pupils to catchment areas. Therefore, we have an upper bound on the fraction of pupils who are assigned to the wrong catchment area: $14 \%$. To gauge the sensitivity of our estimates to this amount of measurement error, we have randomly re-assigned $14 \%$ of all pupils to a new catchment area (within their municipality). We have then re-estimated our regressions on a data set where neighbourhood segregation has been calculated using data with additional measurement error in pupils' assignment to catchment areas. Results from this exercise are shown in tables in Appendix 4, which should be compared to our preferred baseline specifications in columns 6 of Tables 2,3,4 and 5. For each outcome, Table 12 presents results from two different specifications. The first

\footnotetext{
${ }^{37}$ An alternative approach to interpreting the size of the estimates is to relate them to the maximum amount of overexposure that would occur under complete isolation of the two groups. For example, overexposure under complete isolation of pupils with Swedish/foreign background amounts to 1.17 (1.32) in 1993 (2009). As such, the shift in segregation predicted by school choice, from an overexposure ratio of 1.0005 to 1.0085 , is to be considered small.

${ }^{38}$ The Herfindahl index is given by $H=\sum_{i=1}^{N} s_{i}^{2}$, where $s$ is the market share (i.e. share of pupils) of school $i$, and $N$ is the number of schools. The index ranges from $1 / \mathrm{N}$ to 1 . The higher the value of the index, the lower is competition.
} 
Table 6 Sensitivity analysis: First difference models of changes in school segregation

\begin{tabular}{|c|c|c|c|c|}
\hline & \multicolumn{4}{|c|}{$\Delta$ Own-group overexposure } \\
\hline & $\begin{array}{l}\text { Immigrant } \\
\text { (1) }\end{array}$ & $\begin{array}{l}\text { Immigrant } \\
\text { background } \\
\text { (2) }\end{array}$ & $\begin{array}{l}\text { Parental } \\
\text { income } \\
(3)\end{array}$ & $\begin{array}{l}\text { Parental } \\
\text { education } \\
\text { (4) }\end{array}$ \\
\hline$\Delta$ Share of independent schools & $\begin{array}{l}0.013 \\
(0.005)^{*}\end{array}$ & $\begin{array}{l}0.028 \\
(0.014)^{*}\end{array}$ & $\begin{array}{l}0.039 \\
(0.013)^{* *}\end{array}$ & $\begin{array}{l}0.051 \\
(0.019)^{* *}\end{array}$ \\
\hline $\begin{array}{l}\Delta \text { Herfindahl index (based on public school } \\
\text { pupils) }\end{array}$ & $\begin{array}{l}-0.005 \\
(0.003)\end{array}$ & $\begin{array}{l}0.006 \\
(0.012)\end{array}$ & $\begin{array}{l}-0.032 \\
(0.013)^{*}\end{array}$ & $\begin{array}{l}-0.043 \\
(0.018)^{*}\end{array}$ \\
\hline Observations & 181 & 181 & 184 & 184 \\
\hline Demographic controls 1993 & $\mathrm{X}$ & $\mathrm{X}$ & $\mathrm{X}$ & $\mathrm{X}$ \\
\hline Control for neighbourhood overexposure & $\mathrm{X}$ & $\mathrm{X}$ & $\mathrm{X}$ & $\mathrm{X}$ \\
\hline Control for expected exposure by location & $\mathrm{X}$ & $\mathrm{X}$ & $\mathrm{X}$ & $\mathrm{X}$ \\
\hline
\end{tabular}

Notes: First difference regressions of the change (2009-1993) in own-group overexposure on measures of changes in school choice. The Herfindahl index is set to 1 in all municipalities in the pre-reform period. Demographic controls in 1993 are listed in Table 1. Robust standard errors in parentheses

+ significant at $10 \%$; significant at $5 \%$; ** significant at $1 \%$

specification introduces measurement error only in the calculation of 'neighbourhood segregation' at the municipality/year level. The second specification also introduces measurement error in the calculation of the fraction of pupils opting out to a different public school (i.e. the variable 'public choice').

The overall impression from the estimations that have introduced additional measurement error is that the coefficients on school choice are slightly larger than in the baseline specification, and that the coefficients on neighbourhood segregation are slightly lower. This pattern is in line with the intuition that measurement error might lead to a downward bias in the neighbourhood segregation coefficient. As it turns out, this also introduces an upward bias in the estimation of the school choice parameters. The key insight from Appendix Table 12 is therefore that measurement error might lead to a small bias in our results. However, this bias does not change our conclusions either qualitatively or quantitatively.

\section{Concluding discussion}

We have conducted an exploratory study trying to gain a deeper understanding of the potential sources behind the increased school segregation in Sweden since the implementation of a school choice reform in the early 1990s. To address the question of which are the most important mechanisms behind school segregation, we reason that the three main determinants are neighbourhood segregation, parental choice and indirect cream skimming through independent schools' location choices. We are able to assess these three components, exploiting a policy change that introduced generalized school choice in Sweden: prior to the reform, students were assigned to their neighbourhood school through catchment areas, whereas after the reform parental school choice and location decisions by independent schools became factors that could influence school segregation. Variation in these 
determinants is explored both over time (pre- and post-reform) and across space, since school choice opportunities have evolved very differently across regions in Sweden. Despite the existence of this reform and the regional variation in choice opportunities it created, it is very challenging to separately identify the importance of each of these mechanisms. Does school choice generate school segregation, or is demand for choice higher in highly segregated areas? Is the evolution of neighbourhood segregation exogenous, or is it a reaction to increased choice opportunities? We simply cannot say with certainty that school segregation in regions with a lot of choice opportunities after the reform, would have evolved similarly to segregation in the regions without choice opportunities, had the reform not been implemented.

Despite these challenges we have been able to reveal a number of interesting findings. First, neighbourhood segregation is the main explanation for school segregation, also in the post-reform period when families had the possibility to opt out of their assigned schools. Second, the geographic locations of newly established independent schools do not seem to contribute to increased school segregation. Third and finally, school segregation has increased more in regions where school choice has become more prevalent and has stayed roughly constant in regions with very few choice opportunities, and segregation at the residential level cannot fully explain the increase in school segregation. In other words, school segregation has increased more than what would be the case if all pupils attended their assigned schools. The key finding of the study is that choice to independent voucher schools is positively associated with increased school segregation between immigrants and natives, and between pupils of immigrant/Swedish background. This association is robust to a number of specifications and sensitivity analyses that exploit alternative sources of variation in choice and that attempt to control for the fact that neighbourhood segregation may be affected by the reform in itself. In order to understand the magnitudes of our estimates, we compare school segregation in Sweden to that of other western countries, and conclude that the changes in school segregation that can be attributed to choice are relatively small, at least in an international perspective.

What is the significance of these results for the Swedish context? Even though Sweden still ranks as a low-to-medium segregated country in an international comparison, it is important to follow how school segregation evolves as the independent school sector keeps growing. It is also clear that although independent schools are not allowed to cream-skim or to charge tuition, other policies to limit tendencies towards segregation and to make schools accessible to all are possible. One example is to tie the voucher to the socioeconomic background of the pupil in order to introduce a compensatory element in the choice programme (as already in effect in Chile and the Netherlands). Another example is to assign pupils by way of a lottery when an independents school is oversubscribed (as is the case for charter schools in the USA), and to provide information about school quality that is accessible to all parents. When it comes to more strict regulations regarding where independent schools should locate (such as for charter schools), our results do not suggest that location patterns so far have contributed to segregation in Sweden.

Our results are of great interest in an international context. Several countries are observing an expanding sector of non-public schools and/or experimenting with school choice policies. If these countries wish to introduce choice but limit pupil segregation, the challenge lies in the design of the system and the various mechanisms that affect parental choice and the allocation of pupils to schools. Our results suggest that also in a voucher system without cream skimming and tuition fees, school choice can result in increased segregation. 
Acknowledgments The authors would like to thank the anonymous referees for helpful comments and suggestions.

\section{Compliance with ethical standards}

Funding This study was funded by the Swedish Research Council for Health, Working Life and Welfare (FORTE) (grant number 2013-0645), the Swedish Research Council (grant number D0199201; 2007-2283) and the European Research Council (ERC starting grant number 241161).

Conflict of interest The authors declare that they have no conflict of interest.

\section{Appendix 1: School choice in Sweden}

Table 7 Percent pupils in different groups attending an independent school in 2009

All

Immigrant

Native

Immigrant background

Swedish background

Parental income above median

Parental income below median

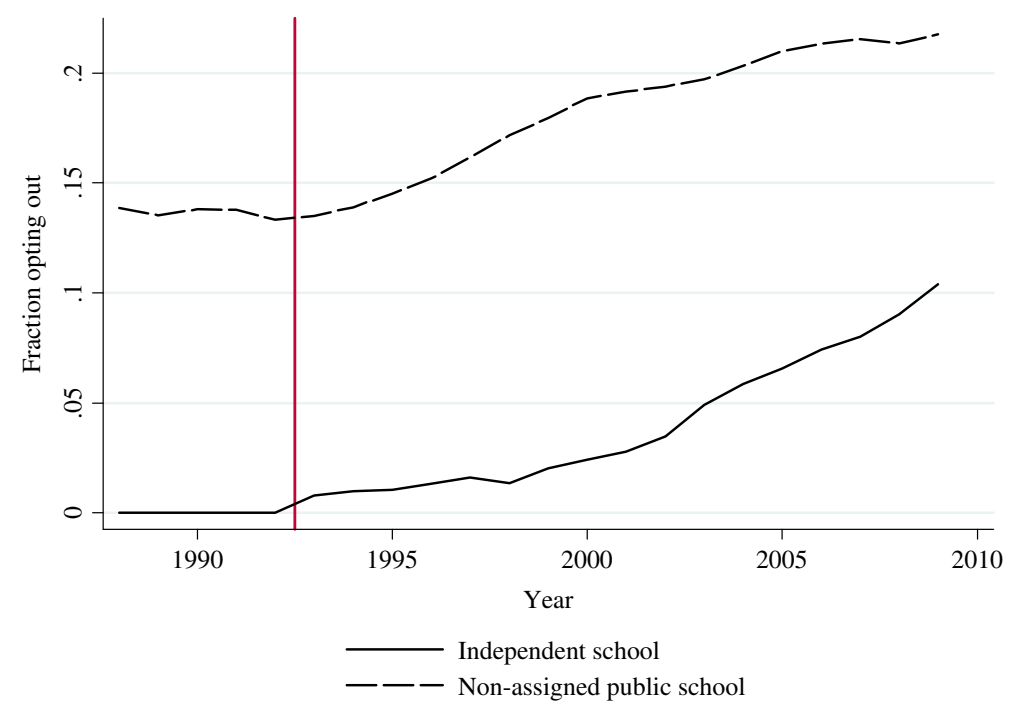

Fig. 5 The fraction of pupils opting out to independent and non-assigned public schools 
Figure 5 shows the share of students opting out to independent schools and to non-assigned public in Sweden between 1988 and 2009. ${ }^{39}$ The share of students in private non-voucher schools before the reform is approximated to zero.

\section{Appendix 2: Segregation measured as overexposure}

We use the measure of own-group overexposure presented in Åslund and Nordström Skans (2009). We assume that the population consists of $\mathrm{M}$ students and is divided into two groups $\mathrm{g}$ of size $\mathrm{N}_{\mathrm{g}}$, and define student i:s exposure to her own group g as follows:

$$
e_{i g s}=\frac{1}{n_{s}-1} \sum_{j \in s_{j \neq i}} D_{j g}
$$

where $D=1$ for individuals belonging to group $\mathrm{g}$, and $n$ is the number of students in schools. This is simply a measure of the number of schoolmates belonging to the same group g, divided by the total number of school mates (i.e. school size minus one). Average own-group exposure is given by:

$$
\bar{e}=\frac{1}{M} \sum_{g=1}^{2} \sum_{i \in g} e_{i g s}
$$

where student i:s exposure to her own group is summed over all individuals in group g, and next summed over the two groups in the population, and divided with the size of the population. Hence, $\bar{e}$ measures own-group exposure for all students, regardless which group they belong to. We next consider how these measures of exposure can be used to account for segregation under random allocation. If we assume that students were randomly allocated to schools, each school mate of a given student would belong to group 1 with probability $\mathrm{N}_{1} / \mathrm{M}$ and to group 2 with probability $\mathrm{N}_{2} / \mathrm{M}$. That is, under random allocation, we would expect exposure to a specific group to be equal to the fraction of students belonging to that group in the population as a whole. We can therefore define average expected own-group exposure under random allocation as:

$$
\bar{e}^{\text {random }}=\frac{1}{M} \sum_{g=1}^{2} \sum_{i \in g}\left(\frac{N_{g}}{M}\right)_{i g s}
$$

Now we can relate actual own-group exposure to expected exposure under random allocation, and we obtain the own-group overexposure ratio $R=\frac{\bar{e}}{\bar{e}^{\text {random }} \text {. }}$

Maximum overexposure $\left(R^{\max }\right)$ occurs under complete isolation of the two groups. $R^{\max }$ depends on the group shares of the two groups, and reaches 2 for groups of equal size. In our application $R^{\max }$ is 2 for segregation by education and income background, where the high/low education/income groups are defined by the median in each cohort's distribution. For segregation between immigrants and natives, and between pupils of Swedish and foreign background, $R^{\max }$ ranges between 1.131.20 and 1.17-1.30, respectively, depending on the group proportions in different cohorts.

We can also define expected own-group exposure, given independent schools' locations. The aim of this hypothetical exercise is to understand whether it is independent schools' locations, as opposed to parental choice, that give rise to segregation trends. The independent school student population is assumed to have the average characteristics of the neighbourhood (SAMS-unit) where the school is

\footnotetext{
${ }^{39}$ The share of independent school students includes students from all voucher-receiving schools (including international schools and those special pedagogy schools for which we lack grades).
} 
located. In other words, we assign the expected values given by the neighbourhood where the school is located, to the fractions of pupils of each group that should be expected to go to the school given its location. Remaining students are assigned the population mean. The intuition is that we want to estimate to what extent independent schools are located in areas that deviate from the population average.

$$
\bar{e}^{\text {indep }}=\frac{1}{M}\left(\sum_{g=1}^{2}\left[\sum_{i \in p}\left(\frac{N_{g, p, n b}}{M_{p, n b}}\right)_{i p s}+\sum_{i \in m}\left(\frac{N_{g}}{M}\right)_{i m s}\right]\right)
$$

where $\mathrm{p}=$ expected private (independent) school students (i.e. the fraction of students of each group that is expected to attend the school if it were to admit students that are representative of the SAMS-unit); $\mathrm{m}=$ expected municipal (public school) students and $\frac{N_{g, p, n b}}{M_{p, n b}}$ is the group share in the neighbourhood where the independent school is located, and $\frac{N_{g}}{M}$ is the population average of group g. Not that we expect $R=\frac{e^{\text {indep }}}{\bar{e}^{\text {random }}}>1$ if independent schools sort into neighbourhoods that imply higher own-group exposure than the average, and $R=\frac{\bar{e}^{\text {indep }}}{\bar{e}^{\text {random }}}<1$ if schools sort into neighbourhoods that imply lower own-group exposure than the average.

Figure 6 shows how the measure of own-group overexposure corresponds to Carrington and Troske's (1997) index of systematic dissimilarity.
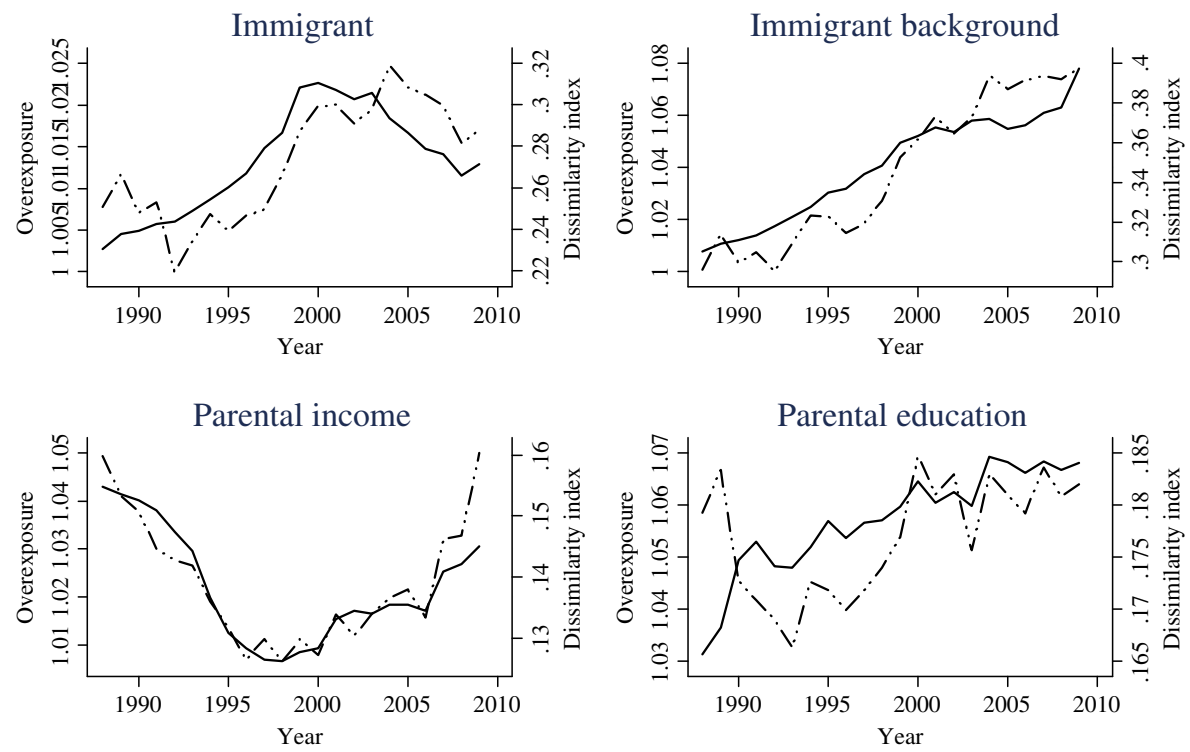

Overexposure

Dissimilarity index

Fig. 6 A comparison of school segregation measured with the overexposure index and the index of systematic dissimilarity. Note: The dissimilarity index uses Carrington and Troske's (1997) adjustment for segregation under random allocation 


\section{Appendix 3}

Table 8 Fixed effects model of school segregation between immigrants and natives

Own-group overexposure: immigrant/native
(1)
(2)
(3)
(4)
(5)
(6)

\begin{tabular}{ll}
\hline Share total choice & 0.012 \\
$(0.004)^{* *}$
\end{tabular}

Share indep. school choice

0.031

$(0.013)^{*}$

Share public school choice

0.003

(0.005)

Neighbourhood overexposure

Expected exposure by location

Observations

R-squared

3995

0.63

Demographic controls

Note: All regressions include municipality and year fixed effects (181 municipalities, years: 1988-2009). Demographic controls are listed in Table 1. Standard errors clustered at the municipality level in parentheses + significant at $10 \% ; *$ significant at $5 \%$; * significant at $1 \%$

Table 9 Fixed effects model of school segregation between pupils of immigrant/Swedish background

Own-group overexposure: immigrant background/Swedish background

(2) (3)

(4)

(5)

(6)
(1)

0.069

Share total choice

$(0.019)^{* *}$

Share indep. school choice

Share public school choice

Neighbourhood overexposure

Expected exposure by location

Observations

R-squared

4002

0.163
$(0.060)^{* *}$
0.020
$(0.012)$

Demographic controls

0.012

Note: See Table 8

Springer 
Table 10 Fixed effects model of school segregation between pupils of high/low parental income

Own-group overexposure: high/low parental income

\begin{tabular}{lllll}
\hline & $(2)$ & (1) & (4) & (5)
\end{tabular}

\begin{tabular}{|c|c|c|c|c|c|c|}
\hline Share total choice & $\begin{array}{l}0.035 \\
(0.009)^{* *}\end{array}$ & & & & & \\
\hline Share indep. school choice & & $\begin{array}{l}0.068 \\
(0.022)^{* *}\end{array}$ & & & $\begin{array}{l}0.027 \\
(0.016)+\end{array}$ & $\begin{array}{l}0.028 \\
(0.017)\end{array}$ \\
\hline Share public school choice & & $\begin{array}{l}0.019 \\
(0.008)^{*}\end{array}$ & & & $\begin{array}{l}0.021 \\
(0.008)^{* *}\end{array}$ & $\begin{array}{l}0.021 \\
(0.008)\end{array}$ \\
\hline Neighbourhood overexposure & & & $\begin{array}{l}0.505 \\
(0.035)^{* *}\end{array}$ & & $\begin{array}{l}0.501 \\
(0.034)^{* *}\end{array}$ & $\begin{array}{l}0.498 \\
(0.033)^{* *}\end{array}$ \\
\hline Expected exposure by location & & & & $\begin{array}{l}0.150 \\
(0.062)^{*}\end{array}$ & $\begin{array}{l}-0.045 \\
(0.060)\end{array}$ & $\begin{array}{l}-0.049 \\
(0.066)\end{array}$ \\
\hline Observations & 4048 & 4046 & 4048 & 4048 & 4046 & 4046 \\
\hline R-squared & 0.65 & 0.65 & 0.78 & 0.64 & 0.78 & 0.79 \\
\hline Demographic controls 1993 & & & & & & $\mathrm{x}$ \\
\hline
\end{tabular}

Note: See Table 8

Table 11 Fixed effects model of school segregation between pupils of high/low parental education

Own-group overexposure: high/low parental education

\begin{tabular}{llllll}
\hline & $(2)$ & (1) & (4) & (4)
\end{tabular}

\begin{tabular}{|c|c|c|c|c|c|c|}
\hline Share total choice & $\begin{array}{l}0.025 \\
(0.009)^{* *}\end{array}$ & & & & & \\
\hline Share indep. school choice & & $\begin{array}{l}0.054 \\
(0.024)^{*}\end{array}$ & & & $\begin{array}{l}0.048 \\
(0.023)^{*}\end{array}$ & $\begin{array}{l}0.062 \\
(0.025)^{*}\end{array}$ \\
\hline Share public school choice & & $\begin{array}{l}0.011 \\
(0.011)\end{array}$ & & & $\begin{array}{l}0.020 \\
(0.009)^{*}\end{array}$ & $\begin{array}{l}0.023 \\
(0.009)^{* *}\end{array}$ \\
\hline Neighbourhood overexposure & & & $\begin{array}{l}0.426 \\
(0.026)^{* *}\end{array}$ & & $\begin{array}{l}0.427 \\
(0.026)^{* *}\end{array}$ & $\begin{array}{l}0.426 \\
(0.026)^{* *}\end{array}$ \\
\hline Expected exposure by location & & & & $\begin{array}{l}0.157 \\
(0.069)^{*}\end{array}$ & $\begin{array}{l}-0.013 \\
(0.068)\end{array}$ & $\begin{array}{l}-0.052 \\
(0.064)\end{array}$ \\
\hline Observations & 4048 & 4046 & 4048 & 4048 & 4046 & 4046 \\
\hline R-squared & 0.69 & 0.69 & 0.77 & 0.68 & 0.77 & 0.77 \\
\hline Demographic controls & & & & & & $\mathrm{x}$ \\
\hline
\end{tabular}

Note: See Table 8 


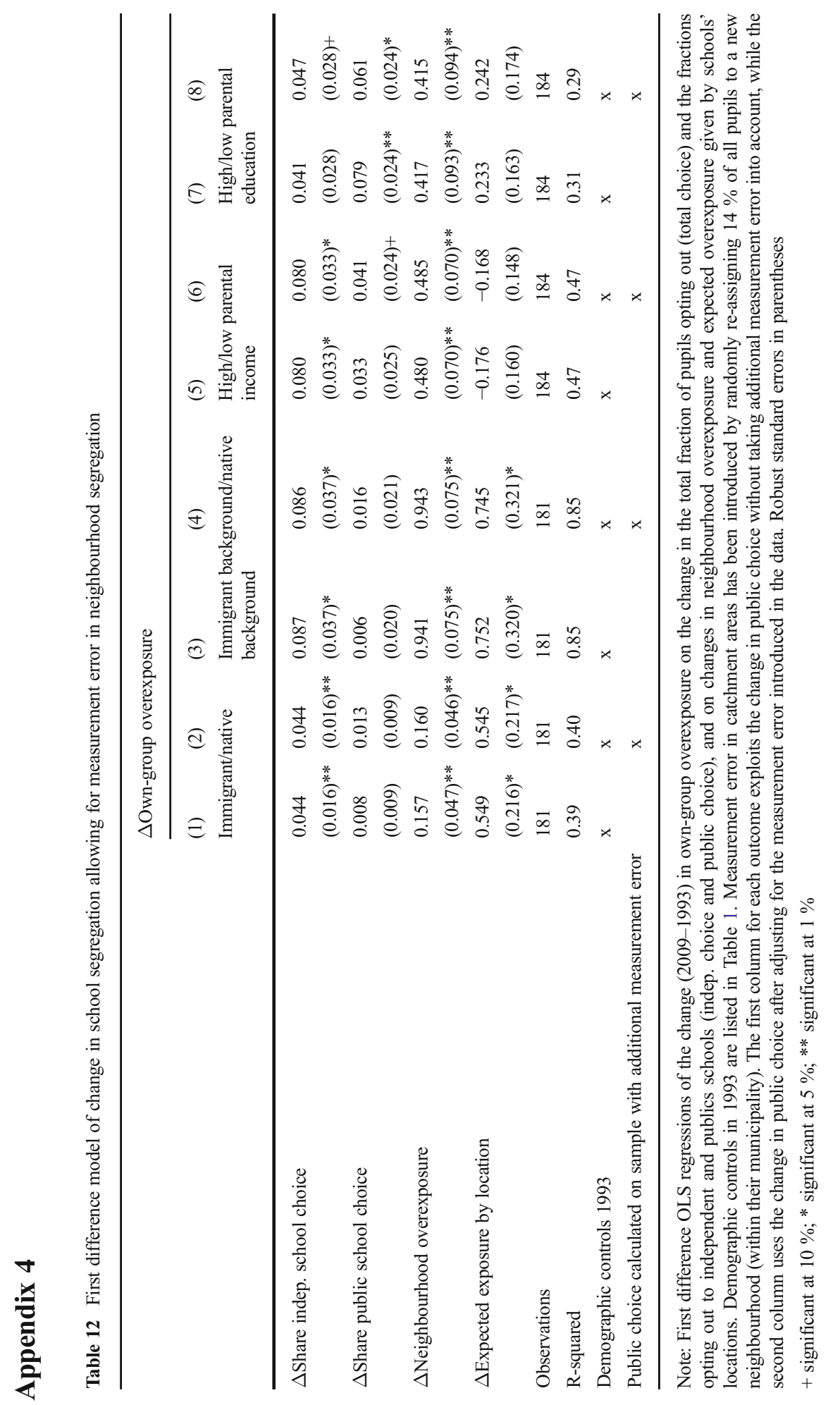


Open Access This article is distributed under the terms of the Creative Commons Attribution 4.0 International License (http://creativecommons.org/licenses/by/4.0/), which permits unrestricted use, distribution, and reproduction in any medium, provided you give appropriate credit to the original author(s) and the source, provide a link to the Creative Commons license, and indicate if changes were made.

\section{References}

Andersson E, Malmberg B, Östh J (2012) Travel-to-school distances in Sweden 2000-2006: changing school geography with equality implications. J Transp Geogr 23:35-43

Åslund O, Nordström Skans O (2009) How to measure segregation conditional on the distribution of covariates. J Popul Econ 22(4):971-981

Åslund O, Nordström Skans O (2010) Will I see you at work? Ethnic workplace segregation in Sweden 19852002. Ind Labor Relat Rev 63(3):471-493

Allen R, Vignoles A (2007) What should an index of school segregation measure? Oxf Rev Educ 33(5):643668

Barseghyan L, Clark D, Coate S (2014) Public school choice: an economic analysis. NBER working paper 20701

Bell W (1957) A probability model for the measurement of ecological segregation. Social Forces 32(4):357364

Billings SB, Deming DJ, Rockoff JE (2014) School segregation, educational attainment and crime: evidence from the end of busing in Charlotte-Mecklenburg. Q J Econ 129(1):435-476

Böhlmark A, Lindahl M (2015) Independent schools and long-run educational outcomes-evidence from Sweden's large scale voucher reform. Economica 82:508-551

Burgess S, McConnell B, Popper C, Wilson D (2007) The impact of school choice on sorting by ability and socio-economic factors in English secondary education. In: Woessmann L, Peterson P (eds) Schools and the equal opportunity problem. MIT Press, Cambridge, US, pp 273-292

Card D, Mas A, Rothstein J (2008) Tipping and the dynamics of segregation. Q J Econ 123(1):177-218

Carrington WJ, Troske KR (1997) On measuring segregation in samples with small units. J Bus Econ Stat 15(4):402-409

Duflo E, Dupas P, Kremer M (2011) Peer effects and the impacts of tracking: evidence from a randomized evaluation in Kenya. Am Econ Rev 101(5):1739-1774

Edmark K, Frölich M, Wondratschek V (2014) Sweden's school choice reforms and equality of opportunity. Labour Econ 30:129-142

Epple D, Romano R (2008) Educational vouchers and cream skimming. Int Econ Rev 49(4):1395-1435

Figlio D, Stone J (2001) Can public policy affect private school cream skimming? J Urban Econ 49(2):240266

Fredriksson P, Vlachos J (2011) Reformer och resultat: Kommer regeringens utbildningsreformer att ha någon betydelse? Rapport till Finanspolitiska rådet 2011/3

Gibbons S, Machin S, Silva O (2008) Choice, competition and pupil achievement. J Eur Econ Assoc 6(4): 912-947

Hastings J, Kane T, Staiger D (2005) Parental preferences and school competition: evidence from a public school choice program. NBER Working Paper No 11805

Hellerstein JK, Neumark D (2008) Workplace segregation in the United States: race, ethnicity, and skill. Rev Econ Stat 90(3):459-477

Hensvik L (2012) Competition, wages and teacher sorting: lessons learned from a voucher reform. Econ J 122(561):799-824

Holmlund H, Häggblom J, Lindahl E, Martinson S, Sjögren A, Vikman U, Öckert B (2014) Decentralisering, skolval och fristående skolor: resultat och likvärdighet i svensk skola. IFAU Rep 2014:25

Hsieh CT, Urquiola M (2006) The effects of generalized school choice on achievement and stratification: evidence from Chile's voucher program. J Public Econ 90:1477-1503

Hutchens R (2004) One measure of segregation. Int Econ Rev 45(2):555-578

Jenkins SP, Micklewright J, Schnepf SV (2008) Social segregation in secondary schools: how does England compare with other countries? Oxf Rev Educ 34(1):21-37

Ladd H, Fiske E (2001) The uneven playing field of school choice: evidence from New Zealand. J Policy Anal Manag 20(1):43-63

Levin H (1998) Educational vouchers: effectiveness, choice, and costs. J Policy Anal Manag 17(3):373-392 
Malmberg B, Andersson EK, Bergsten Z (2014) Composite geographical context and school choice attitudes in Sweden: a study based on individually defined, scalable neighborhoods. Ann Assoc Am Geogr 104(4): 869-888

Massey DS, Denton NA (1988) The dimensions of residential segregation. Soc Forces 67(2):281-315

MacLeod W B, Urquiola M (2009) Anti-lemons: school reputation and educational quality. NBER Working Paper No 15112

MacLeod W B, Urquiola M (2012) Competition and educational productivity: incentives writ large. IZA Discussion paper 7063

Swedish Ministry of Education (2011) Uppdrag att stödja skolor i utanförskapsområden. Report U2011/6863/ $\mathrm{S}$

Swedish National Agency for Education (2012) Likvärdig utbildning i svensk grundskola? En kvantitativ analys av likvärdighet över tid. Report 374

National Alliance for Public Charter Schools (NAPCS) (2014) The public charter schools dashboard downloaded 12 February 2015 from: http://www.publicchartersorg/dashboard/schools/year/2014

Nechyba TJ (2006) Income and peer quality sorting in public and private schools. In: Hanushek E, Welch F (eds) Handbook of the Economics of Education, North Holland

Nordström Skans O, Åslund O (2009) Segregationen in storstäderna. SNS välfärdsrapport, Stockholm

Östh J, Andersson E, Malmberg B (2013) School choice and increasing performance difference: a counterfactual approach. Urban Stud 50(2):406-424

Schnepf SV (2004) How different are immigrants? A cross-country and cross-survey analysis of educational achievement. Southampton Statistical Sciences Research Institute Applications \& Policy Working Paper A04/15

Shafiq MN, Myers JP (2014) Educational vouchers and social cohesion: a statistical analysis of student civic attitudes in Sweden, 1999-2009. Am J Educ 121(1):111-136

Ruist J (2015) Refugee immigration and public finances in Sweden. WP in Economics No 613, University of Gothenburg

Spaiser V, Hedström P, Jansson K, Nordvik M, Sumpter D (2016) Identifying complex dynamics in social systems: the case of school segregation. Sociol Methods Res. doi:10.1177/0049124116626174

SVT (2013) Friskolor väljer bort besvärliga elever. Downloaded from http://www.svtse/ug/friskolor-valjerbort-besvarliga-elever Published 28 oktober 2013. Downloaded 28 January 2013

Söderström M, Uusitalo R (2010) School choice and segregation: evidence from an admission reform. Scand J Econ 122(1):55-76

Tiebout C (1956) A pure theory of local expenditures. J Polit Econ 64(5):416-424

Wondratschek V, Edmark K, Frölich M (2013) The short and long-term effects of school choice on student outcomes - evidence from a school choice reform in Sweden. Ann Econ Stat 111-112:71-102

Wong DWS (1997) Spatial dependency of segregation indices. Can Geogr 41(2):128-136 